\title{
Article \\ Hydrogen Production through Autothermal Reforming of Ethanol: Enhancement of Ni Catalyst Performance via Promotion
}

\author{
Ekaterina Matus ${ }^{1} \mathbb{D}$, Olga Sukhova ${ }^{1}$, Ilyas Ismagilov ${ }^{1, *}$, Mikhail Kerzhentsev $^{1}\left(\mathbb{D}\right.$, Olga Stonkus $^{1}{ }^{1}$ and \\ Zinfer Ismagilov ${ }^{1,2}$
}

1 Boreskov Institute of Catalysis SB RAS, 630090 Novosibirsk, Russia; matus@catalysis.ru (E.M.); sukhova@catalysis.ru (O.S.); ma_k@catalysis.ru (M.K.); stonkus@catalysis.ru (O.S.); zinfer1@mail.ru (Z.I.)

2 Federal State Budget Scientific Centre «The Federal Research Center of Coal and Coal-Chemistry of Siberian Branch of the Russian Academy of Sciences», 650000 Kemerovo, Russia

* Correspondence: iismagil@catalysis.ru

Citation: Matus, E.; Sukhova, O.; Ismagilov, I.; Kerzhentsev, M.; Stonkus, O.; Ismagilov, Z. Hydrogen Production through Autothermal Reforming of Ethanol: Enhancement of Ni Catalyst Performance via Promotion. Energies 2021, 14, 5176. https://doi.org/10.3390/en14165176

Academic Editor: Luca Gonsalvi

Received: 30 June 2021

Accepted: 17 August 2021

Published: 21 August 2021

Publisher's Note: MDPI stays neutral with regard to jurisdictional claims in published maps and institutional affiliations.

Copyright: (C) 2021 by the authors Licensee MDPI, Basel, Switzerland. This article is an open access article distributed under the terms and conditions of the Creative Commons Attribution (CC BY) license (https:// creativecommons.org/licenses/by/ $4.0 /)$.

\begin{abstract}
Autothermal reforming of bioethanol (ATR of $\mathrm{C}_{2} \mathrm{H}_{5} \mathrm{OH}$ ) over promoted $\mathrm{Ni} / \mathrm{Ce}_{0.8} \mathrm{La}_{0.2} \mathrm{O}_{1.9}$ catalysts was studied to develop carbon-neutral technologies for hydrogen production. The regulation of the functional properties of the catalysts was attained by adjusting their nanostructure and reducibility by introducing various types and content of $\mathrm{M}$ promoters $(\mathrm{M}=\mathrm{Pt}, \mathrm{Pd}, \mathrm{Rh}, \mathrm{Re}$; molar ratio $\mathrm{M} / \mathrm{Ni}=0.003-0.012$ ). The composition-characteristics-activity correlation was determined using catalyst testing in ATR of $\mathrm{C}_{2} \mathrm{H}_{5} \mathrm{OH}$, thermal analysis, $\mathrm{N}_{2}$ adsorption, $X$-ray diffraction, transmission electron microscopy, and EDX analysis. It was shown that the type and content of the promoter, as well as the preparation mode (combined or sequential impregnation methods), determine the redox properties of catalysts and influence the textural and structural characteristics of the samples. The reducibility of catalysts improves in the following sequence of promoters: $\mathrm{Re}<\mathrm{Rh}<\mathrm{Pd}<\mathrm{Pt}$, with an increase in their content, and when using the co-impregnation method. It was found that in ATR of $\mathrm{C}_{2} \mathrm{H}_{5} \mathrm{OH}$ over bimetallic Ni-M/Ce $\mathrm{C}_{0.8} \mathrm{La}_{0.2} \mathrm{O}_{1.9}$ catalysts at $600{ }^{\circ} \mathrm{C}$, the hydrogen yield increased in the following row of promoters: $\mathrm{Pt}<\mathrm{Rh}<\mathrm{Pd}<\mathrm{Re}$ at $100 \%$ conversion of ethanol. The introduction of $\mathrm{M}$ leads to the formation of a NiM alloy under reaction conditions and affects the resistance of the catalyst to oxidation, sintering, and coking. It was found that for enhancing Ni catalyst performance in $\mathrm{H}_{2}$ production through ATR of $\mathrm{C}_{2} \mathrm{H}_{5} \mathrm{OH}$, the most effective promotion is with Re: at $600{ }^{\circ} \mathrm{C}$ over the optimum $10 \mathrm{Ni}-0.4 \mathrm{Re} / \mathrm{Ce}_{0.8} \mathrm{La}_{0.2} \mathrm{O}_{1.9}$ catalyst the highest hydrogen yield $65 \%$ was observed.
\end{abstract}

Keywords: renewable hydrogen; biofuel; reforming of bioethanol; bimetallic catalyst; modifier

\section{Introduction}

Currently, there is a rapid growth in the population of the Earth. Over the past 200 years, the number of people has grown by $\sim 6$ billion, reaching 7.8 billion in 2020 . According to forecasts, by the end of the century, the world's population will reach 11 billion people $[1,2]$. To meet the demand of a growing population, the world needs more and more energy every year. Fossil fuels continue to be the main source of energy resources. Humanity consumes $\sim 22$ million tons of coal, $\sim 12$ million tons of oil, and $\sim 10$ billion $\mathrm{m}^{3}$ of natural gas per day [3]. The constant growth in fossil fuel consumption is accompanied by an increase in the concentration of carbon dioxide in the atmosphere, which is the cause of climate change. To reduce the negative impacts on the environment and rational use of natural resources, it is urgent to develop technologies for the decarbonization of the energy system [4-6]. This is in line with the global strategy to reduce greenhouse gas emissions and the realization of the Paris Agreement's tasks to create a climate-neutral society by 2050 [7].

Under these conditions, hydrogen energy has already been recognized as a reasonable decision in the struggle for climate neutrality [8,9]. By 2050, it is expected that $24 \%$ of 
the world's energy needs will be met by hydrogen. The priority is to obtain renewable hydrogen, produced mainly with the use of wind and solar energy. In the short and medium term, low carbon footprint technologies will prevail, leading to reduced $\mathrm{CO}_{2}$ emissions. Currently, the volume of hydrogen production in the world is estimated at 75 million tons per year and is expected to increase by $30 \%$ in the next five years [10]. Reforming natural gas is one of the main conventional ways of hydrogen production [11-15]. This is the least expensive and energy-efficient method, but to prevent $\mathrm{CO}_{2}$ emissions, the use of carbon capture and storage technology is required [16,17]. It is advisable for the production of hydrogen to use biofuels (biogas, bioethanol), the source of which can be a renewable raw material-biomass [18-24].

Bioethanol takes the top place in the list of liquid biofuels. World bioethanol production in 2020 amounted to 26 billion gallons [25]. The world leader in the bioethanol production is the United States, which generated about 13.8 billion gallons. The secondlargest producer country is Brazil, which produced 7.9 billion gallons of ethanol. The bulk of bioethanol is derived from corn and sugar cane. Various agricultural crops with a high starch or sugar content can also become raw materials for the bioethanol production, for example, cassava, potatoes, sugar beets, sweet potatoes, sorghum, barley, etc. The raw materials can also be various agricultural and forestry waste: wheat straw, rice straw, sugarcane bagasse, sawdust. The growth of biomass is accompanied by the consumption of atmospheric $\mathrm{CO}_{2}$. Thus, using bioethanol as a feedstock in $\mathrm{H}_{2}$ production reduces the consumption of fossil fuels and provides carbon neutrality of technology.

The most efficient process for producing hydrogen from ethanol is autothermal reforming (ATP of $\left.\mathrm{C}_{2} \mathrm{H}_{5} \mathrm{OH}\right)$ [26]:

$$
\mathrm{CH}_{3} \mathrm{CH}_{2} \mathrm{OH}+1.8 \mathrm{H}_{2} \mathrm{O}+0.6 \mathrm{O}_{2} \longrightarrow 4.8 \mathrm{H}_{2}+2 \mathrm{CO}_{2} \Delta \mathrm{H}^{\mathrm{o}}{ }_{298}=+4.4 \mathrm{~kJ} / \mathrm{mol}
$$

The energy neutrality of this reaction makes it possible to refer it to energy-saving processes. In addition to the favorable energy balance, this process is characterized by a high yield of $\mathrm{H}_{2}$. The effective conversion of bioethanol requires the solution of important problems of increasing the activity of catalysts and their resistance to deactivation. The chemical formula and nanostructure of catalysts strongly affect $\mathrm{H}_{2}$ yield and the composition of the reaction products in ATR of $\mathrm{C}_{2} \mathrm{H}_{5} \mathrm{OH}$ [27-30]. The mode of the first stages of ethanol transformation (dehydrogenation to acetaldehyde or dehydration to ethylene) depends mainly on the properties of the support [26]. Diffusion and transformation of $\mathrm{C}_{2}$-intermediates are controlled by the metal-support interface, while the decomposition of $\mathrm{C}_{2}$-intermediates and the conversion of $\mathrm{C}_{1}$-reaction products occur with the participation of metal centers of the active component. The noble metals $\mathrm{Rh}, \mathrm{Ag}, \mathrm{Au}, \mathrm{Pd}, \mathrm{Pt}, \mathrm{Ru}, \mathrm{Re}$, as well as $\mathrm{Ni}$, or $\mathrm{Co}$, are used as an active metal, while for stabilization of their highly dispersed forms, various oxides $\left(\mathrm{SiO}_{2}, \mathrm{MgO}, \mathrm{La}_{2} \mathrm{O}_{3}, \mathrm{CeO}_{2}-\mathrm{Al}_{2} \mathrm{O}_{3}, \mathrm{CeO}_{2}-\mathrm{La}_{2} \mathrm{O}_{3}, \mathrm{CeMnO}_{2}\right.$, $\mathrm{MgAl}_{2} \mathrm{O}_{4}$ ) are applied as support [31-35].

Cerium dioxide is a suitable support for ATR of $\mathrm{C}_{2} \mathrm{H}_{5} \mathrm{OH}$ catalysts due to its redox properties, high oxygen capacity, and the possibility of realization of the strong metalsupport interaction [36-40]. The intrinsic catalytic activity of $\mathrm{CeO}_{2}$-based supports and the degree of their interaction with the active component can be regulated by its doping. It was shown that among the tested dopants $(\mathrm{M}=\mathrm{Gd}, \mathrm{La}, \mathrm{Mg})$, La has a more pronounced positive effect on the state and functionality of $\mathrm{Ni}^{-} \mathrm{Ce}_{1-\mathrm{x}} \mathrm{M}_{\mathrm{x}} \mathrm{O}_{\mathrm{y}}(\mathrm{M}=\mathrm{Gd}, \mathrm{La}, \mathrm{Mg}, \mathrm{x}=0-0.9$, $1.5 \leq \mathrm{y} \leq 2.0)$ [41-44]. The introduction of La as a modifier in the support composition enhances the metal-support interaction, which improves Ni dispersion and catalyst stability under the ATR of $\mathrm{C}_{2} \mathrm{H}_{5} \mathrm{OH}$. However, it also leads to a diminution of $\mathrm{Ni}^{\mathrm{n}+}$ reducibility that can decrease the concentration of $\mathrm{Ni}^{\circ}$ active sites and, consequently, $\mathrm{H}_{2}$ yield.

The introduction of a promoter is a rather wide-spread approach directed to the improvement of functional characteristics of $\mathrm{Ni}$ catalysts developed for various catalytic processes [45-49]. It is shown that bimetallic catalysts have advantages over monometallic ones in the reforming of $\mathrm{C}_{2} \mathrm{H}_{5} \mathrm{OH}[31,35,50-53]$. In particular, it is indicated [35] that for $\mathrm{Ni} / \mathrm{CeMnO}_{2}$, the introduction of $\mathrm{Cu}$ or Fe increased the ethanol conversion from 57 to 
$70 \%$ and $61 \%$ consequently. $\mathrm{Ni}-\mathrm{Fe} / \mathrm{CeMnO}_{2}$ catalyst provides higher hydrogen yield $(60 \%)$ among the other samples because of conducting the reaction to dehydrogenation route, while the feature of $\mathrm{Ni}-\mathrm{Co} / \mathrm{CeMnO}_{2}$ sample was high $\mathrm{CO}$ selectivity due to the impact of $\mathrm{Co}$ in the progress of water-gas shift reaction. It is noted that an increase of $\mathrm{H}_{2}$ yield over $\mathrm{Ni}-\mathrm{Co} / \mathrm{Ce}-\mathrm{Zr}-\mathrm{O}$ and $\mathrm{Ni}-\mathrm{Pd} / \mathrm{SiO}_{2}$ catalysts is correlated with an increase of reducibility of the bimetallic sample in comparison with appropriate monometallic Ni catalyst [31,50]. The $\mathrm{Ru}$ or Rh additives stabilized Co metallic phase under operation in oxidative conditions [54]. A study of a series of $\mathrm{Cu}-\mathrm{Ni} / \mathrm{SiO}_{2}$ catalysts with different $\mathrm{Cu} / \mathrm{Ni}$ molar ratios showed that the $\mathrm{Cu}$-rich catalysts had a higher resistance of coking [55]. Thus, the mechanism of action of the promoter is specific and strongly depends on the composition and method of preparation of the catalyst. It is possible to increase the reducibility of the active component, improve its dispersion or resistance to coking.

This work is devoted to the development of effective bimetallic catalysts for hydrogen production through ATR of $\mathrm{C}_{2} \mathrm{H}_{5} \mathrm{OH}$. To improve the functional properties of the $\mathrm{Ni} / \mathrm{Ce}_{0.8} \mathrm{La}_{0.2} \mathrm{O}_{1.9}$ catalysts, their nanostructure and reducibility were regulated by introducing various types and content of $\mathrm{M}$ promoters $(\mathrm{M}=\mathrm{Pt}, \mathrm{Pd}, \mathrm{Rh}, \mathrm{Re}$; molar ratio $\mathrm{M} / \mathrm{Ni}=0.003-0.012)$.

\section{Materials and Methods}

The Ni-M/ $\mathrm{Ce}_{0.8} \mathrm{La}_{0.2} \mathrm{O}_{1.9}$ catalysts $(\mathrm{M}=\mathrm{Pt}, \mathrm{Pd}, \mathrm{Rh}$, and $\mathrm{Re}$; molar ratio $\mathrm{M} / \mathrm{Ni}=0.003-0.012)$ were prepared by the combined incipient wetness impregnation method unless otherwise specified. For this, $\mathrm{Ce}_{0.8} \mathrm{La}_{0.2} \mathrm{O}_{1.9}$ support was impregnated by an aqueous solution of the mixture $(\mathrm{Ni}+\mathrm{M})$ of metal precursors with a specified concentration. The description of the preparation mode and properties of the $\mathrm{Ce}_{0.8} \mathrm{La}_{0.2} \mathrm{O}_{1.9}$ support can be found in our previous paper [56]. After the impregnation, the Ni-M/Ce ${ }_{0.8} \mathrm{La}_{0.2} \mathrm{O}_{1.9}$ catalysts were dried at $90{ }^{\circ} \mathrm{C}$ for $6 \mathrm{~h}$, calcined at $500{ }^{\circ} \mathrm{C}$ for $4 \mathrm{~h}$ in the air. The $\mathrm{Ni}\left(\mathrm{NO}_{3}\right)_{2} \cdot 6 \mathrm{H}_{2} \mathrm{O}$ was used as $\mathrm{Ni}$ precursor, while $\mathrm{H}_{2} \mathrm{PtCl}_{6} \cdot 6 \mathrm{H}_{2} \mathrm{O}, \mathrm{Pd}\left(\mathrm{NO}_{3}\right)_{2}, \mathrm{RhCl}_{3} \cdot 3 \mathrm{H}_{2} \mathrm{O}$, or $\mathrm{NH}_{4} \mathrm{ReO}_{4}$ compounds were used as precursors for $\mathrm{Pt}, \mathrm{Pd}, \mathrm{Rh}$, or Re promoters, respectively.

In some specially stipulated cases, the catalysts were obtained by the sequential incipient wetness impregnation method. In this case, the $\mathrm{Ce}_{0.8} \mathrm{La}_{0.2} \mathrm{O}_{1.9}$ support was impregnated by an aqueous solution of $\mathrm{Ni}\left(\mathrm{NO}_{3}\right)_{2} \cdot 6 \mathrm{H}_{2} \mathrm{O}$ with a given concentration. After the impregnation, the $\mathrm{Ni} / \mathrm{Ce}_{0.8} \mathrm{La}_{0.2} \mathrm{O}_{1.9}$ catalyst was dried at $90{ }^{\circ} \mathrm{C}$ for $6 \mathrm{~h}$, calcined at $500{ }^{\circ} \mathrm{C}$ for $4 \mathrm{~h}$ in the air, and then impregnated by an aqueous solution of a promoter (M) precursor with a specified concentration. Then Ni-M/Ce ${ }_{0.8} \mathrm{La}_{0.2} \mathrm{O}_{1.9}$ samples were dried at $90{ }^{\circ} \mathrm{C}$ for $6 \mathrm{~h}$ and calcined at $500{ }^{\circ} \mathrm{C}$ for $4 \mathrm{~h}$ in the air.

The Ni content was equal to $10 \mathrm{wt} . \%$, while the molar ratio $\mathrm{M} / \mathrm{Ni}$ was 0.003 or 0.012 . The samples are noted according to their composition and synthesis procedure: the number means the molar ratio $\mathrm{M} / \mathrm{Ni}$, while " $\mathrm{C}$ " and " $\mathrm{S}$ " correspond to the samples obtained by combined and sequential impregnation, respectively.

The catalysts were thoroughly studied by X-ray fluorescence spectroscopy, thermal analysis (TA) (thermogravimetric (TG), differential thermogravimetric (DTG), and differential thermal analysis (DTA)), $\mathrm{N}_{2}$ adsorption, $\mathrm{X}$-ray diffraction, transmission electron microscopy, and EDX analysis. A description of devices and conditions for studying materials by physicochemical methods can be found in our earlier publications $[41,44,47]$.

ATR of $\mathrm{C}_{2} \mathrm{H}_{5} \mathrm{OH}$ was investigated in a flow setup with a quartz reactor $(14 \mathrm{~mm}$ i.d.) at atmospheric pressure, temperature $200-700{ }^{\circ} \mathrm{C}$, a flow rate of $230 \mathrm{~mL} / \mathrm{min}$ and the molar ratio between reagents $\mathrm{C}_{2} \mathrm{H}_{5} \mathrm{OH}: \mathrm{H}_{2} \mathrm{O}: \mathrm{O}_{2}: \mathrm{He}=1: 3: 0.5: 1$ according to the method described in [41]. Note that the influence of the reaction conditions $\left(500-700{ }^{\circ} \mathrm{C}, \mathrm{C}_{2} \mathrm{H}_{5} \mathrm{OH}: \mathrm{H}_{2} \mathrm{O}=1-4\right.$, $\mathrm{C}_{2} \mathrm{H}_{5} \mathrm{OH}: \mathrm{O}_{2}=0.2-0.8$ ) was preliminarily studied, and the optimal molar ratio of the reagents for the maximum hydrogen yield was selected. In contrast to our previous studies [41,57], there was no reduction of catalysts before catalytic activity tests. In this case, the active centers will be formed directly under the reaction conditions. The ability to self-activate in the reaction environment ensures that the catalyst can operate on a daily 
start-up and shut-down cycle without requiring activation before use [58]. It is essential for hydrogen production through reforming for fuel cell technology $[59,60]$.

\section{Results and Discussion}

\subsection{Characteristics of the $\mathrm{Ni}-\mathrm{M} / \mathrm{Ce}_{0.8} \mathrm{La}_{0.2} \mathrm{O}_{1.9}$}

The Ni-M/ $\mathrm{Ce}_{0.8} \mathrm{La}_{0.2} \mathrm{O}_{1.9}$ samples were prepared by the incipient wetness impregnation method, in which precursors of the active component are introduced into the support matrix followed by thermal treatment. The characteristics of the decomposition of metal precursors and the formation of catalysts have been studied by thermal analysis. Figure 1 demonstrates typical TG, DTG, and DTA curves of dried unpromoted and promoted Ni catalysts.

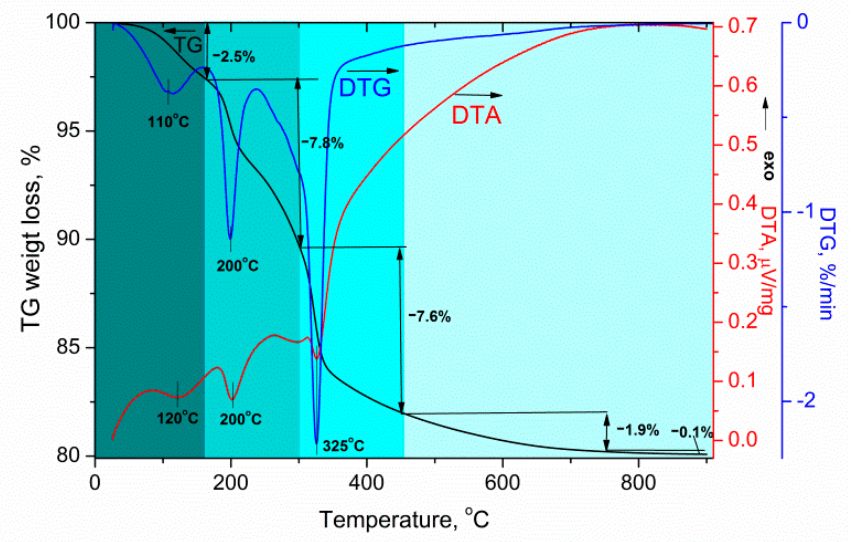

(a)

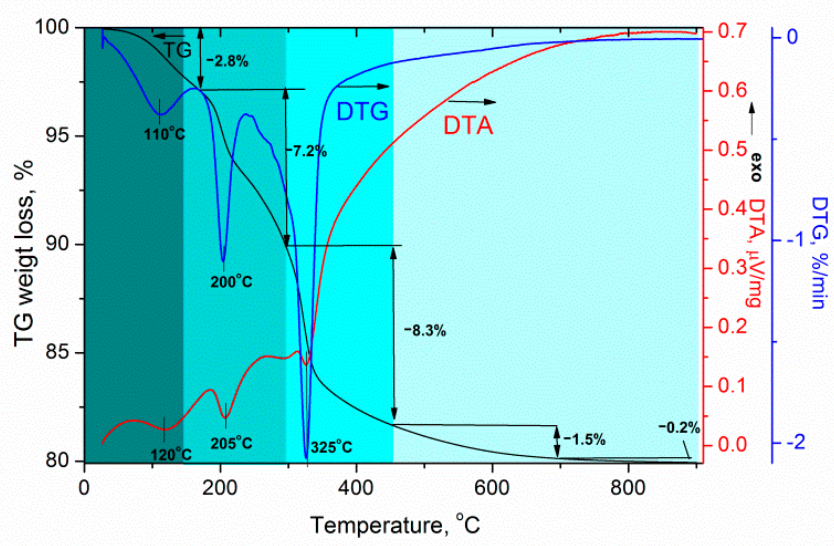

(b)

Figure 1. Thermal analyses in the air of dried Ni (a) and Ni-Pt-0.012 (C) (b) catalysts.

For Ni catalyst in a low-temperature region $\left(\mathrm{T}<150{ }^{\circ} \mathrm{C}\right)$, an endothermic effect at $\mathrm{T}_{\mathrm{DTA}}=125^{\circ} \mathrm{C}$ is observed. It is accompanied by a weight loss $(-\Delta \mathrm{m} / \mathrm{m}=2.5 \%)$ through water desorption. In the temperature range $150-350{ }^{\circ} \mathrm{C}$, there are two endothermic effects at $\mathrm{T}_{\mathrm{DTA}}=200$ and $325^{\circ} \mathrm{C}$. The weight losses of 7.8 and $7.6 \%$ were connected with the decomposition of nitrate nickel hydrate to anhydrous $\mathrm{Ni}\left(\mathrm{NO}_{3}\right)_{2}$ and then transformation of $\mathrm{Ni}\left(\mathrm{NO}_{3}\right)_{2}$ to oxide $\mathrm{NiO}$, correspondingly [61]. At a temperature of $450-900{ }^{\circ} \mathrm{C}$, the change in the weight of the sample is apparently associated with dehydroxylation of the support surface. The total weight loss is equal to $17.4 \%$. Similar behavior was observed for all other $\mathrm{Ni}-\mathrm{M} / \mathrm{Ce}_{0.8} \mathrm{La}_{0.2} \mathrm{O}_{1.9}$ catalysts. As an example, on the derivatogram of the $\mathrm{Ni}-\mathrm{Pt} / \mathrm{Ce}_{0.8} \mathrm{La}_{0.2} \mathrm{O}_{1.9}$ sample, there are no effects corresponding to the decomposition of the Pt precursor due to its low content (Figure 1b).

From $\mathrm{N}_{2}$ adsorption data (Figure 2), it follows that fresh Ni-M catalysts are mesoporous materials: the type IV adsorption isotherms with a hysteresis loop of type $\mathrm{H} 3$ are observed, which usually indicates the pore shape is wedged with the opening at both ends or groove pores are formed by flaky particles [62]. Hysteresis at partial pressure $\mathrm{P} / \mathrm{Po}=0.7-1.0$ corresponds to the presence of texture mesoporosity [39]. The samples show bimodal pore size distribution with a maximum at ca. 4 and $18 \mathrm{~nm}$ (Figure 2c).The texture characteristics of the samples are weakly dependent on the type of promoter: $\mathrm{S}_{\mathrm{BET}}=70 \pm 5 \mathrm{~m}^{2} / \mathrm{g}, \mathrm{V}_{\text {pore }}=0.20 \pm 0.01 \mathrm{~cm}^{3} / \mathrm{g}$, and $\mathrm{D}_{\text {pore }}=11.5 \pm 0.9 \mathrm{~nm}$ (Table 1), which are typical values for materials of such composition $[32,35,63]$. When using the sequential impregnation method, there is a tendency to some decrease in specific surface area $\left(69 \rightarrow 56 \mathrm{~m}^{2} / \mathrm{g}\right)$. This is probably due to differences in the heat treatment procedure for these samples. Single calcination at $500{ }^{\circ} \mathrm{C}$ instead of two times reduces the degree of sintering of the material. Note that the specific surface area of the catalysts is $25 \%$ lower 
than the $\mathrm{S}_{\mathrm{BET}}$ of the $\mathrm{Ce}_{0.8} \mathrm{La}_{0.2} \mathrm{O}_{1.9}$ support $\left(94 \mathrm{~m}^{2} / \mathrm{g}\right)$, which is due to the partial jamming of the support pores by particles of the active component.

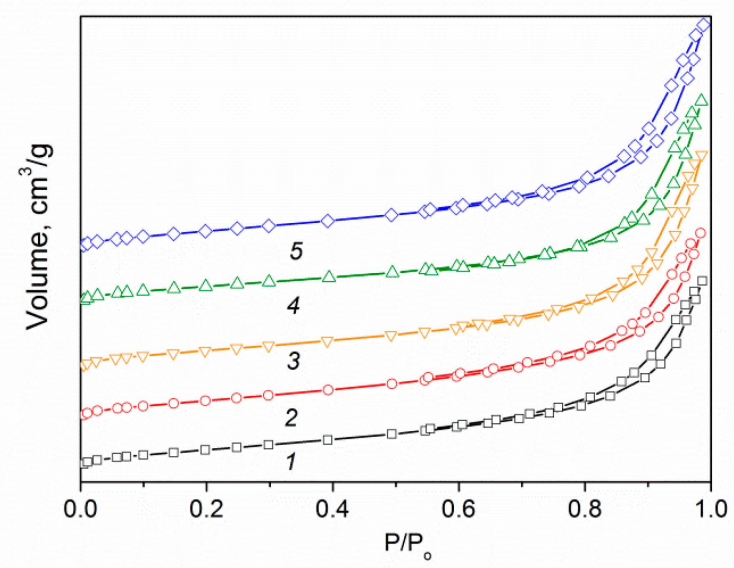

(a)

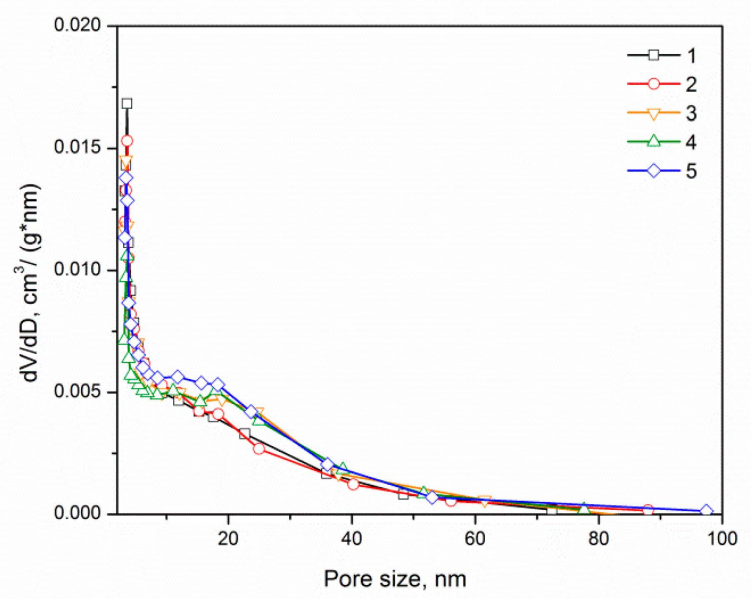

(c)

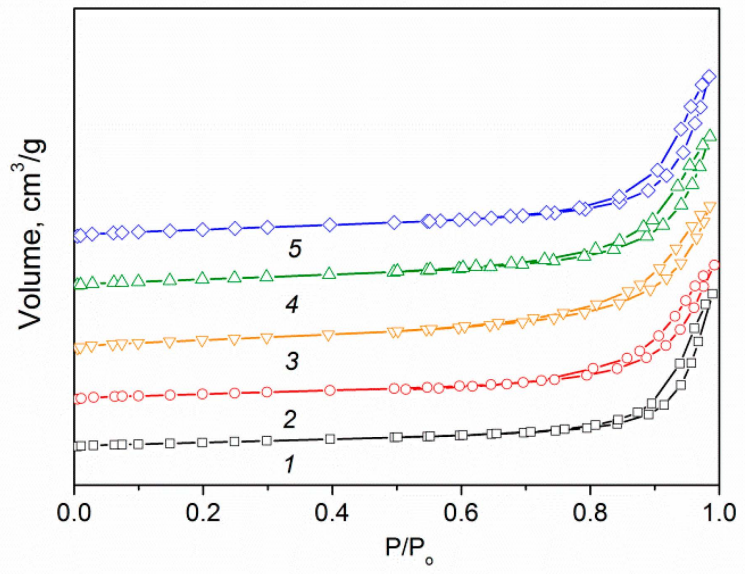

(b)

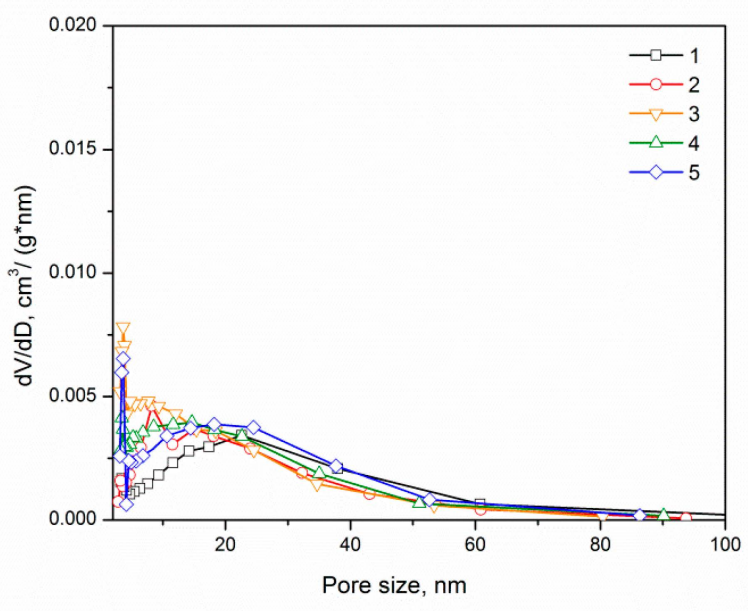

(d)

Figure 2. $\mathrm{N}_{2}$ adsorption-desorption isotherms $(\mathbf{a}, \mathbf{b})$ and pore size distributions $(\mathbf{c}, \mathbf{d})$ for fresh $(\mathbf{a}, \mathbf{c})$ and spent $(\mathbf{b}, \mathbf{d})$ catalysts.

$$
\text { 1-Ni; 2-Ni-Pt-0.012 (C); 3-Ni-Pd-0.012 (C); 4-Ni-Rh-0.012 (C); 5-Ni-Re-0.012 (C). }
$$

XRD patterns of the fresh catalysts are depicted in Figure 3. The pattern of fresh catalysts shows peaks characteristic of the $\mathrm{CeO}_{2}$-based phase of support and $\mathrm{NiO}$ of the active component. The parameter of the unit cell $(a)$ of $\mathrm{CeO}_{2}$-based phase is $5.478 \AA$ that is higher than $a$ of undoped $\mathrm{CeO}_{2}$ (5.411 $\AA$, JCPDS-34-394). This confirms the presence of a $\mathrm{CeO}_{2}$-based solid solution in which some of the $\mathrm{Ce}^{4+}$ cations are replaced by $\mathrm{La}^{3+}$ cations with a larger ionic radius $(0.116 \mathrm{vs} .0 .097 \mathrm{~nm})$.

The coherent scattering region (CSR) was calculated by the Selyakov-Scherrer method from the broadening of the diffraction peak 1.1.1 assigned to phases having a cubic structure of the fluorite type; CSR (NiO)-peak 2.0.0 NiO phases; CSR (Ni)-peak 2.0.0 phases of $\mathrm{Ni}^{\circ}$. The average crystallite size of $\mathrm{CeO}_{2}$-based solid solution is equal to $8.0 \mathrm{~nm}$, and it is the same for all samples. Thus, the phase composition of the support and its structural characteristics do not change as a result of the introduction of $\mathrm{Ni}$ or $\mathrm{Ni}-\mathrm{M}$ active component (Table 1). The average crystallite size of the $\mathrm{NiO}$ phase is slightly smaller for $\mathrm{Ni}, \mathrm{Ni}-\mathrm{Pd}$, and Ni-Rt catalysts in comparison to Ni-Pt and Ni-Re samples (16.5 vs. $19.0 \mathrm{~nm}$ ), which indicates some effect of the second metal. The diffraction patterns of the Ni-M samples 
show no peaks related to the corresponding M-containing phases because of the low content of $\mathrm{M}$ (less than $1 \mathrm{wt} . \%$ ) and its high-dispersed state (Figure 3).

TEM data (Figure 4) confirms the XRD study results. On the surface of $\mathrm{CeO}_{2}$-based solid solution with crystallite size no greater than $10 \mathrm{~nm}, \mathrm{NiO}$ particles of $10-20 \mathrm{~nm}$ in size were observed.

Table 1. Textural and structural characteristics of the Ni-M catalysts.

\begin{tabular}{|c|c|c|c|c|c|c|c|}
\hline & & \multicolumn{3}{|c|}{ Textural Characteristics } & \multicolumn{3}{|c|}{ Structural Characteristics } \\
\hline \multirow{2}{*}{\multicolumn{2}{|c|}{ Sample ${ }^{1}$}} & \multirow{2}{*}{$\begin{array}{l}S_{B E T}, \\
m^{2} / g\end{array}$} & \multirow{2}{*}{$\begin{array}{l}V_{\text {porer }} \\
\mathrm{cm}^{3} / \mathrm{g}\end{array}$} & \multirow{2}{*}{$\begin{array}{c}D_{\text {porer }} \\
\text { nm }\end{array}$} & \multirow{2}{*}{$\begin{array}{c}\text { Phase } \\
\text { Composition }\end{array}$} & \multicolumn{2}{|c|}{ CSR (nm)/Parameter of the Unit Cell (Å) for } \\
\hline & & & & & & $\mathrm{CeO}_{2}$-Based Phase & Ni-Containing Phase \\
\hline $\mathrm{Ce}_{0.8} \mathrm{La}_{0}$ & & 94 & 0.19 & 7.9 & $\mathrm{CeO}_{2}$ & $8.0 / 5.478$ & - \\
\hline \multirow{2}{*}{$\mathrm{Ni}$} & $\mathrm{F}$ & 69 & 0.19 & 10.8 & $\mathrm{CeO}_{2}, \mathrm{NiO}$ & $8.0 / 5.478$ & 16.5 \\
\hline & $\mathrm{S}$ & 24 & 0.15 & 25.7 & $\mathrm{CeO}_{2}, \mathrm{Ni}^{\circ}$ & $18.0 / 5.479$ & $20.0 / 3.525$ \\
\hline \multirow{2}{*}{$\begin{array}{c}\text { Ni-Pt-0.012 } \\
\text { (C) }\end{array}$} & $\mathrm{F}$ & 70 & 0.19 & 10.7 & $\mathrm{CeO}_{2}, \mathrm{NiO}$ & $8.0 / 5.480$ & 16.5 \\
\hline & $\mathrm{S}$ & 26 & 0.14 & 21.0 & $\mathrm{CeO}_{2}, \mathrm{Ni}^{\circ}$ & $14.0 / 5.481$ & $20.0 / 3.526$ \\
\hline \multirow{2}{*}{$\begin{array}{c}\text { Ni-Pd-0.012 } \\
\text { (C) }\end{array}$} & $\mathrm{F}$ & 69 & 0.21 & 12.3 & $\mathrm{CeO}_{2}, \mathrm{NiO}$ & $8.0 / 5.480$ & 17.0 \\
\hline & $\mathrm{S}$ & 41 & 0.15 & 14.5 & $\mathrm{CeO}_{2}, \mathrm{NiPd}$ & $14.0 / 5.483$ & $20.0 / 3.532$ \\
\hline \multirow{2}{*}{$\begin{array}{c}\text { Ni-Rh-0.012 } \\
\text { (C) }\end{array}$} & $\mathrm{F}$ & 64 & 0.20 & 12.4 & $\mathrm{CeO}_{2}, \mathrm{NiO}$ & $8.0 / 5.480$ & 19.0 \\
\hline & $\mathrm{S}$ & 34 & 0.15 & 18.0 & $\mathrm{CeO}_{2}, \mathrm{NiRh}$ & $14.0 / 5.483$ & $20.0 / 3.528$ \\
\hline \multirow{2}{*}{$\begin{array}{c}\text { Ni-Re-0.012 } \\
\text { (C) }\end{array}$} & $\mathrm{F}$ & 75 & 0.22 & 11.9 & $\mathrm{CeO}_{2}, \mathrm{NiO}$ & $8.0 / 5.480$ & 19.0 \\
\hline & $\mathrm{S}$ & 38 & 0.17 & 17.3 & $\mathrm{CeO}_{2}, \mathrm{NiRe}$ & $13.0 / 5.488$ & $16.0 / 3.538$ \\
\hline \multirow{2}{*}{$\begin{array}{c}\text { Ni-Pd-0.003 } \\
(\mathrm{S})\end{array}$} & $\mathrm{F}$ & 62 & 0.19 & 12.0 & $\mathrm{CeO}_{2}, \mathrm{NiO}$ & $8.0 / 5.480$ & 16.5 \\
\hline & $\mathrm{S}$ & 43 & 0.18 & 16.6 & $\mathrm{CeO}_{2}, \mathrm{NiPd}$ & $15.0 / 5.482$ & $20.0 / 3.529$ \\
\hline \multirow{2}{*}{$\begin{array}{c}\text { Ni-Pd-0.012 } \\
\text { (S) }\end{array}$} & $\mathrm{F}$ & 56 & 0.17 & 12.3 & $\mathrm{CeO}_{2}, \mathrm{NiO}$ & $8.0 / 5.480$ & 16.5 \\
\hline & $\mathrm{S}$ & 60 & 0.16 & 11.1 & $\mathrm{CeO}_{2}, \mathrm{NiPd}$ & $15.0 / 5.482$ & $20.0 / 3.532$ \\
\hline
\end{tabular}

${ }^{1}$ F-fresh catalysts (before ATR of $\mathrm{C}_{2} \mathrm{H}_{5} \mathrm{OH}$ ), S-spent catalyst (after ATR of $\mathrm{C}_{2} \mathrm{H}_{5} \mathrm{OH}$ ).

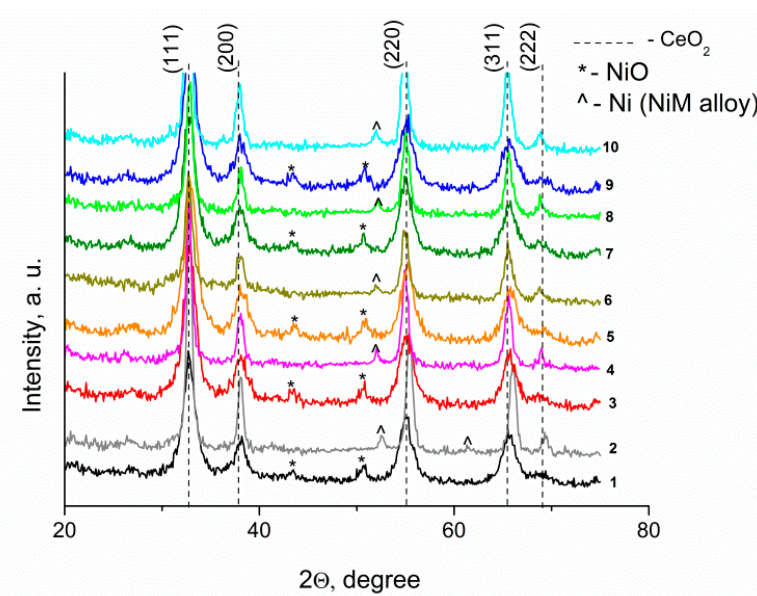

(a)

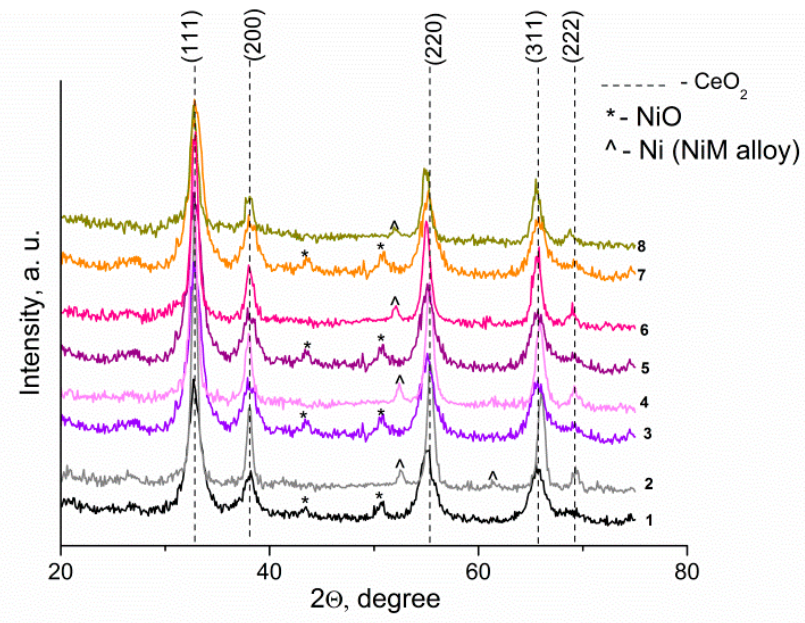

(b)

Figure 3. XRD patterns of fresh (odd numbers) and spent (even numbers) catalysts: influence of promoter type (a), promoter content and synthesis method (b). (a) 1,2-Ni; 3,4-Ni-Pt-0.012 (C); 5,6-Ni-Pd-0.012 (C); 7,8-Ni-Rh-0.012 (C); 9,10-Ni-Re-0.012 (C). (b) 1,2-Ni; 3,4-Ni-Pd-0.003 (S); 5,6-Ni-Pd-0.012 (S); 7,8-Ni-Pd-0.012 (C). 


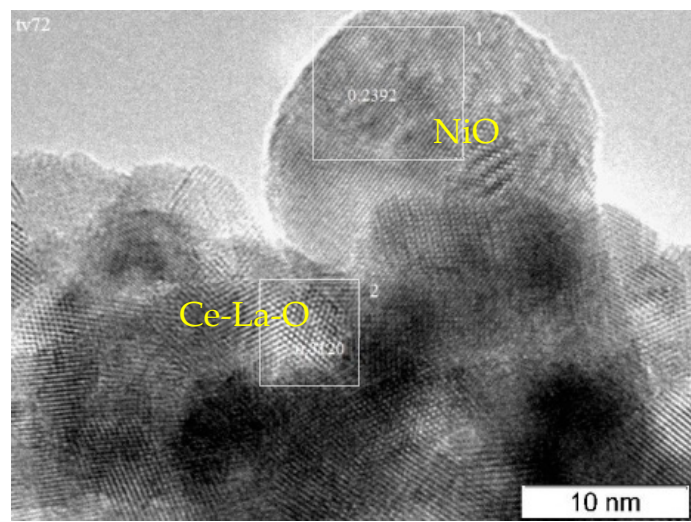

(a)

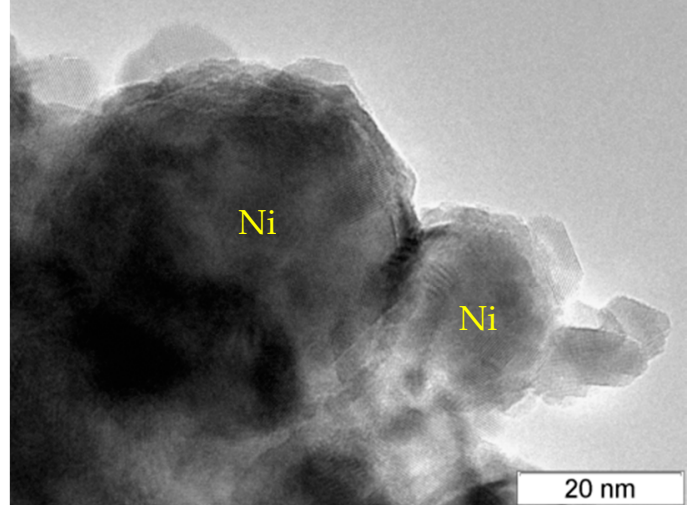

(b)

Figure 4. TEM images of the fresh (a) and spent (b) Ni catalyst.

In the case of catalyst Ni-Pd-0.012 (C), we studied the local distribution of constituent elements using the EDX analysis. Figure 5 shows a HAADF-STEM image of the fresh Ni-Pd-0.012 (C) catalyst with the corresponding EDX maps. It was seen that Ce and La had almost homogeneous distribution in the studied region, which confirmed the formation of a solid $\mathrm{Ce}_{x} \mathrm{La}_{1-\mathrm{x}} \mathrm{O}_{2}$ solution. The opposite situation was observed for nickel: areas with an increased nickel concentration were well seen, which indicated the formation of its separate phase. It agreed well with the XRD data (Table 1). The palladium distribution map did not contain any areas of high concentration. This indicates the absence of individual palladium-containing nanoparticles in the studied area. However, due to the low palladium content, the PdL signal is very weak. Thus, the obtained data do not allow us to conclude whether palladium is located predominantly in the composition of Ni-rich particles or is localized on the surface of the fluorite phase.
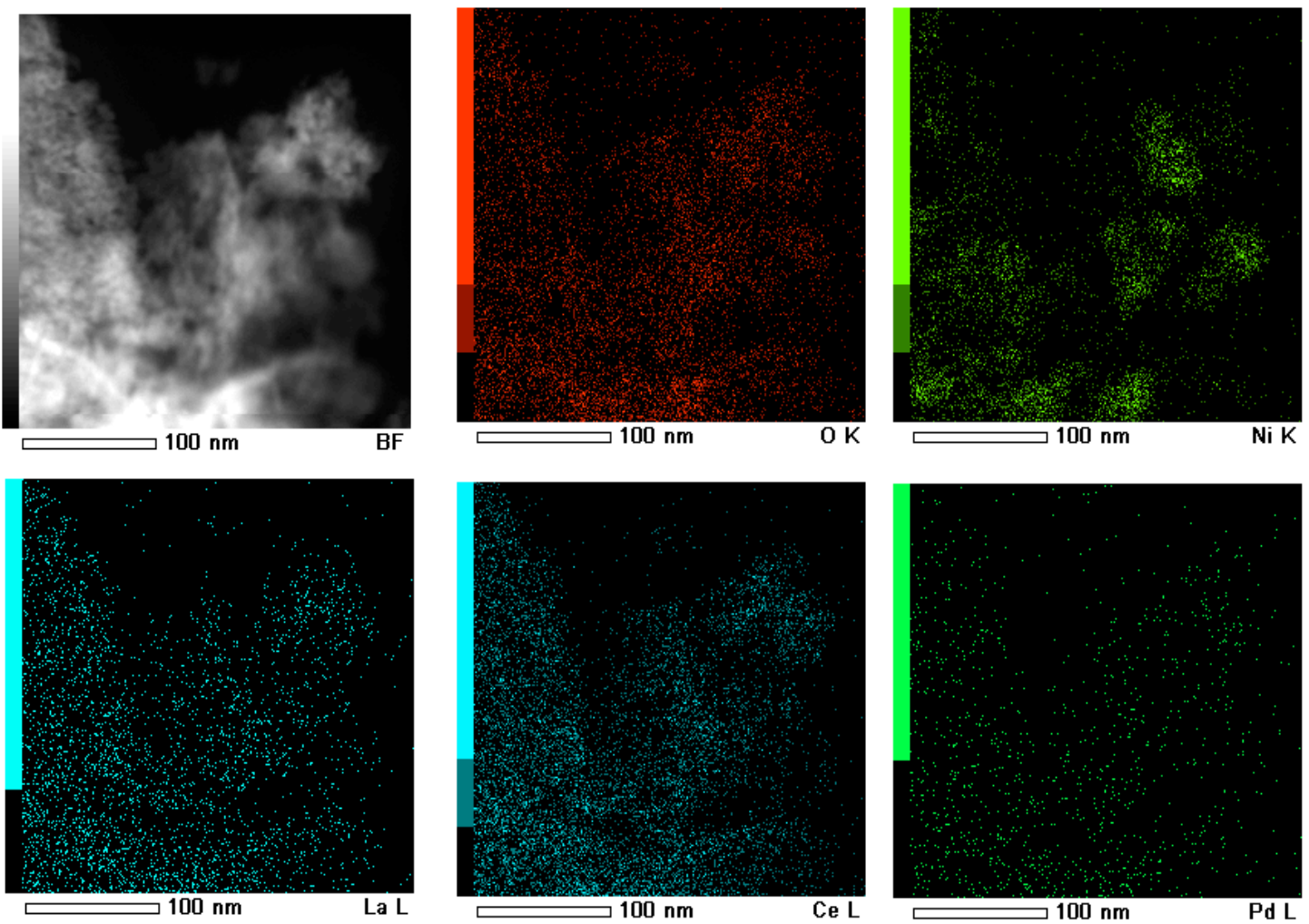

Figure 5. HAADF-STEM image of the fresh Ni-Pd-0.012 (C) catalyst and corresponding EDX mapping patterns. 
The redox properties of the active component are an important characteristic of the reforming catalyst since they determine the concentration of active $\mathrm{Ni}^{\circ}$ centers under the reaction conditions. Typically, the samples were activated by treatment in a hydrogencontaining mixture at a high temperature before the ATR of $\mathrm{C}_{2} \mathrm{H}_{5} \mathrm{OH}$ reaction $[31,33,35]$. This allows nickel oxide to be reduced and $\mathrm{Ni}^{\circ}$ active sites to form. The $\mathrm{Ni}^{\circ}$ state should be preserved under reaction conditions, while re-oxidation of $\mathrm{Ni}^{\circ}$ will lead to catalyst deactivation. A positive quality of reforming catalytic systems is their ability to selfactivate under reaction conditions $[47,48]$. In this case, no additional stage of activation was required, there was no consumption of $\mathrm{H}_{2}$, and active centers were formed directly under the reaction conditions. Thus, to study the effect of the composition of Ni-M catalyst and the method of its synthesis on the reducibility of $\mathrm{Ni}^{2+}$ cations, the samples were studied by the thermal analysis in $\mathrm{H}_{2} / \mathrm{He}$ (Figure 6). There were four temperature regions of weight loss which could be connected with water desorption $\left(\mathrm{T}<200^{\circ} \mathrm{C}\right)$, reduction of nickel oxide $\left(300{ }^{\circ} \mathrm{C}<\mathrm{T}<600^{\circ} \mathrm{C}\right)$, and reduction surface $\left(200{ }^{\circ} \mathrm{C}<\mathrm{T}<300{ }^{\circ} \mathrm{C}\right)$ and bulk $\left(600{ }^{\circ} \mathrm{C}<\mathrm{T}<900{ }^{\circ} \mathrm{C}\right)$ cerium dioxide. For the unpromoted Ni catalyst, three temperature peaks are observed during the reduction of nickel oxide species: at 405,475 , and $545^{\circ} \mathrm{C}$. The observed wide reduction region indicates the presence of various forms of $\mathrm{Ni}^{2+}$ stabilization in the support matrix. It is known [64] that reduction of large particles of $\mathrm{NiO}$, characterized by weak metal-support interaction, occurs in a low-temperature area $\left(\mathrm{T}<500{ }^{\circ} \mathrm{C}\right)$, while highly dispersed particles of $\mathrm{NiO}$, characterized by strong metal-support interaction, is in the high-temperature region $\left(\mathrm{T}>500{ }^{\circ} \mathrm{C}\right)$. It was also shown that the reduction of $\mathrm{Ni}^{2+}$ cations moved to a high-temperature region when the dispersion of Ni-supported nanoparticles and their sintering stability increase due to a decrease of the crystallite size of support [41].

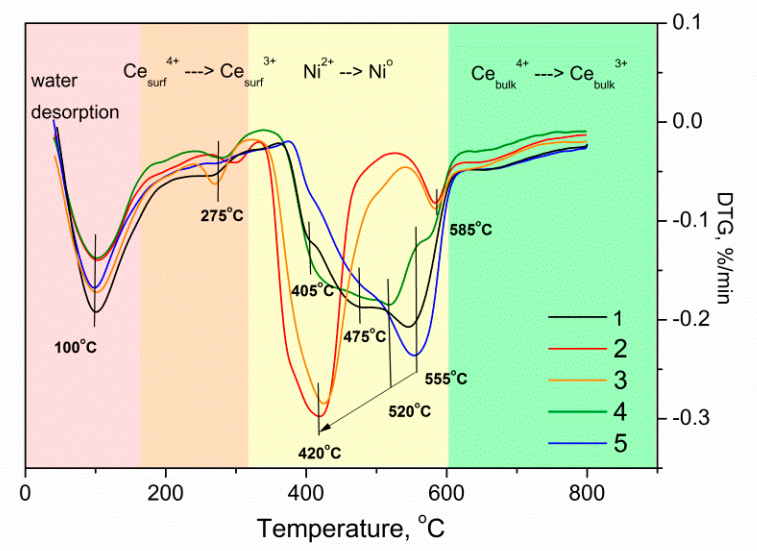

(a)

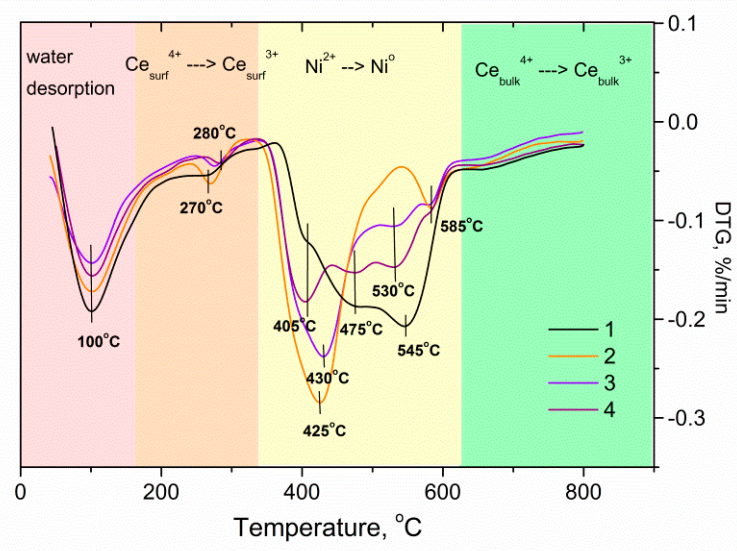

(b)

Figure 6. Thermal analyses in $\mathrm{H}_{2} / \mathrm{He}$ for fresh Ni-M catalysts: effect of promoter type (a) and preparation mode (b). (a) 1-Ni; 2-Ni-Pt-0.012 (C); 3-Ni-Pd-0.012 (C); 4-Ni-Rh-0.012 (C); 5-Ni-Re-0.012 (C). (b) 1-Ni; $2-\mathrm{Ni}-\mathrm{Pd}-0.012$ (C); 3-Ni-Pd-0.012 (S); 4-Ni-Pd-0.003 (S).

With the introduction of a promoter, the behavior of the $\mathrm{Ni}^{2+}$ reduction was changed (Figure 6). In particular, in the presence of $\mathrm{Pt}$ or $\mathrm{Pd}$, the reduction of $\mathrm{Ni}^{2+}$ shifted to the low-temperature region with a maximum at $\sim 420{ }^{\circ} \mathrm{C}$ that could be explained by the $\mathrm{H}_{2}$ spillover effect $[46,58]$. This effect was more pronounced when higher content of promoter or the co-impregnation method of synthesis in contrast to the sequential impregnation method was used (Figure $6 \mathrm{~b}$ ). In the case of $\mathrm{Rh}$, the reduction region remained the same, but the part of difficult-to-reduce $\mathrm{Ni}^{2+}$ species decreased. With the introduction of $\mathrm{Re}$, on the contrary, the part of difficult-to-reduce Ni species increased, and the temperature maximum became equal to $545^{\circ} \mathrm{C}$. Note that due to the low content of promoters, their contribution to the reduction can be ignored in comparison with the reduction peak of $\mathrm{Ni}^{2+}$. 
As a rule, the reduction of $\mathrm{Pt}, \mathrm{Pd}$, and $\mathrm{Rh}$ species occurs at $\mathrm{T}<200{ }^{\circ} \mathrm{C}$, while reduction of $\mathrm{Re}$ cations takes place in the same region where $\mathrm{Ni}^{2+}$ cations are reduced [58,65]. Different reducibility of $\mathrm{Ni}-\mathrm{Re}$ catalysts can be explained by the $\mathrm{Ni}-\mathrm{Re}$ alloy formation under the conditions of TA in $\mathrm{H}_{2}$ / He that changes the kinetics of the active component reduction [66].

The degree of the interaction between metals in the composition of bimetal catalysts is rather different, and it depends on the chemical composition of the catalyst, its preparation method, conditions of its activation, and exploitation [46,67]. In the case of the weak interaction between nickel and a promoter, the formation of monometal particles took place; in the case of the strong interaction, a surface or bulk alloy was formed. It was shown [58] that for the Ni-Pd catalyst, the co-impregnation promoted the formation of bimetallic particles with a more uniform Pd distribution and a lower surface Pd concentration. In the case of sequential impregnation, the formation of bimetallic particles with a high surface $\mathrm{Pd}$ concentration-Pd clusters on the surface of Ni particles took place.

Thus, the type of promoter practically had no effect on the textural and structural properties of fresh Ni-M catalysts. On the contrary, the introduction of even a small amount of a promoter changes the reducibility of the $\mathrm{Ni}$ active component. The reducibility of catalysts improves in the following sequence of promoters $\mathrm{Re}<\mathrm{Rh}<\mathrm{Pd}<\mathrm{Pt}$, with an increase in their content, and when using the co-impregnation method. It is expected that the ability of a catalyst to form dispersed $\mathrm{Ni}^{\mathrm{O}}$ phase and retain it under reaction conditions will control the functional properties of catalysts in ATR of $\mathrm{C}_{2} \mathrm{H}_{5} \mathrm{OH}$.

\subsection{Activity of $\mathrm{Ni}-\mathrm{M} / \mathrm{Ce}_{0.8} \mathrm{La}_{0.2} \mathrm{O}_{1.9}$ Catalysts in ATR of $\mathrm{C}_{2} \mathrm{H}_{5} \mathrm{OH}$}

Figure 7a shows a typical dependence of the conversion of ethanol and the yield of the reaction products in ATP of $\mathrm{C}_{2} \mathrm{H}_{5} \mathrm{OH}$ on temperature. It can be seen that in the presence of the Ni catalyst, the conversion of ethanol to a hydrogen-containing gas increased with an increase in the reaction temperature, reached $100 \%$ at $400{ }^{\circ} \mathrm{C}$, and then did not change (Figure $7 \mathrm{a}$ ). The main reaction products are $\mathrm{H}_{2}, \mathrm{CO}, \mathrm{CO}_{2}$, and $\mathrm{CH}_{4}$. Ethylene, acetaldehyde, and acetone were present in the reaction products in trace amounts only at $\mathrm{T}=300^{\circ} \mathrm{C}$. With an increase in the reaction temperature from 200 to $700{ }^{\circ} \mathrm{C}$, the hydrogen yield increased from 0 to $\sim 43 \%$. The yield of methane $\left(\mathrm{Y}_{\mathrm{CH} 4}\right)$ reached a maximum at a reaction temperature of $400{ }^{\circ} \mathrm{C}$, and then at an increase in the reaction temperature decreased and became less than $1 \%$ at a $\mathrm{T}=700{ }^{\circ} \mathrm{C}$. The $\mathrm{CO}$ yield $\left(\mathrm{Y}_{\mathrm{CO}}\right)$ increased over the temperature range $400-700{ }^{\circ} \mathrm{C}$, and was equal to $\sim 40 \%$ at $700{ }^{\circ} \mathrm{C}$. The behavior of the temperature dependence of $\mathrm{Y}_{\mathrm{CH} 4}$ and $\mathrm{Y}_{\mathrm{CO}}$ indicated an increase in the contribution of the reaction of steam conversion of methane with increasing temperature. The curve of the dependence of the $\mathrm{CO}_{2}$ yield $\left(\mathrm{Y}_{\mathrm{CO} 2}\right)$ on temperature passed through a maximum $(\sim 67 \%)$ at a reaction temperature of $400-500{ }^{\circ} \mathrm{C}$.

The temperature dependence of the activity indices of bimetallic Ni-M catalysts, in general, is similar to those observed in the Ni sample. The advantage of Ni-M systems is a lower temperature to achieve $100 \%$ conversion of ethanol and higher values of hydrogen yield (Figure 7, Table 2). Note that an increase in the promoter content has a positive effect on the process performance, while the method of introducing the metal does not matter (Table 2). 


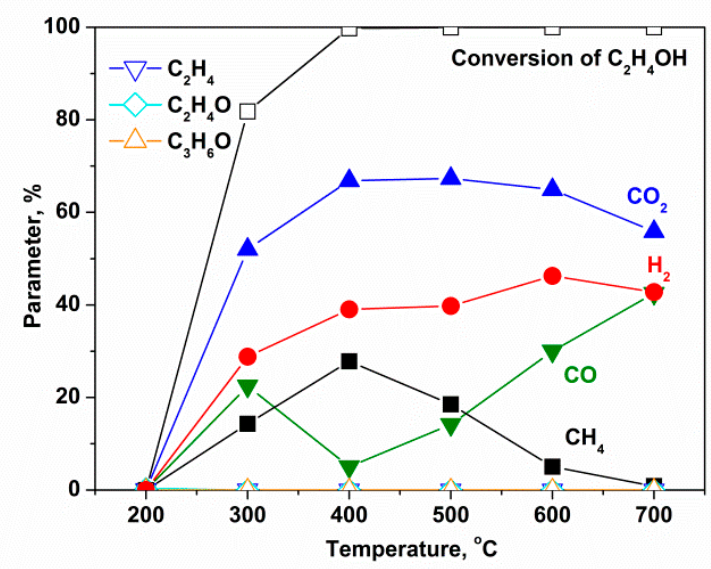

(a)

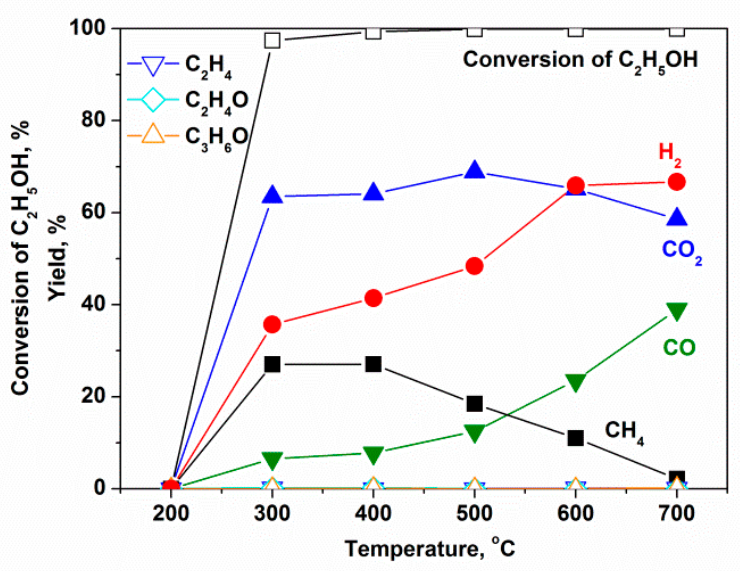

(c)

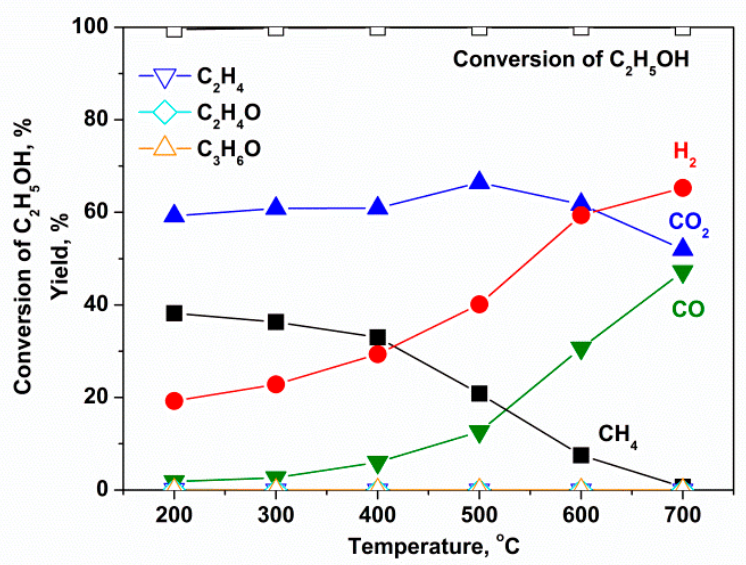

(b)

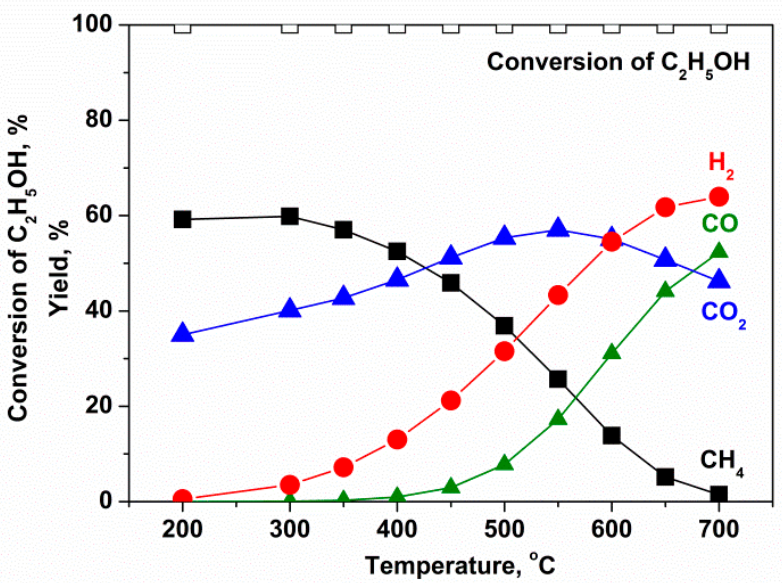

Figure 7. Temperature dependences of $\mathrm{C}_{2} \mathrm{H}_{5} \mathrm{OH}$ conversion and product yield in ATR of $\mathrm{C}_{2} \mathrm{H}_{5} \mathrm{OH}$ over Ni (a), Ni-Pd-0.012 (C) (b), Ni-Re-0.012 (c) catalysts, and thermodynamic equilibrium values (d).

Table 2. Activity of Ni-M catalysts in ATR of $\mathrm{C}_{2} \mathrm{H}_{5} \mathrm{OH}$ at $600{ }^{\circ} \mathrm{C}^{1}$.

\begin{tabular}{ccccc}
\hline Catalyst & $\mathbf{H}_{\mathbf{2}}$ Yield, $\%$ & CO & $\begin{array}{c}\text { Selectivity, } \\
\mathbf{C O}_{\mathbf{2}}\end{array}$ & $\mathbf{C H}_{\mathbf{4}}$ \\
\hline $\mathrm{Ni}$ & 46 & 30 & 65 & 5 \\
$\mathrm{Ni}-\mathrm{Pt}-0.012(\mathrm{C})$ & 51 & 27 & 66 & 7 \\
$\mathrm{Ni}-\mathrm{Pd}-0.012(\mathrm{C})$ & 59 & 31 & 62 & 7 \\
$\mathrm{Ni}-\mathrm{Rh}-0.012(\mathrm{C})$ & 54 & 30 & 64 & 6 \\
Ni-Re-0.012 (C) & 65 & 24 & 65 & 11 \\
Ni-Pd-0.003 (S) & 50 & 22 & 66 & 12 \\
Ni-Pd-0.012 (S) & 58 & 22 & 67 & 11 \\
\hline
\end{tabular}

${ }^{1}$ Conversion of $\mathrm{C}_{2} \mathrm{H}_{5} \mathrm{OH}$ was equal to $100 \%$. 
At $600{ }^{\circ} \mathrm{C}$, the hydrogen yield increased in the next row of promoters $\mathrm{Pt}<\mathrm{Rh}<\mathrm{Pd}<$ Re at $100 \%$ conversion of ethanol (Figure 8 ). For the Ni-Re sample, the obtained parameters of ATR reaction were close to thermodynamic equilibrium values, and the maximum $\mathrm{H}_{2}$ yield (65\%) was attained (Figures 7 and 8$)$.

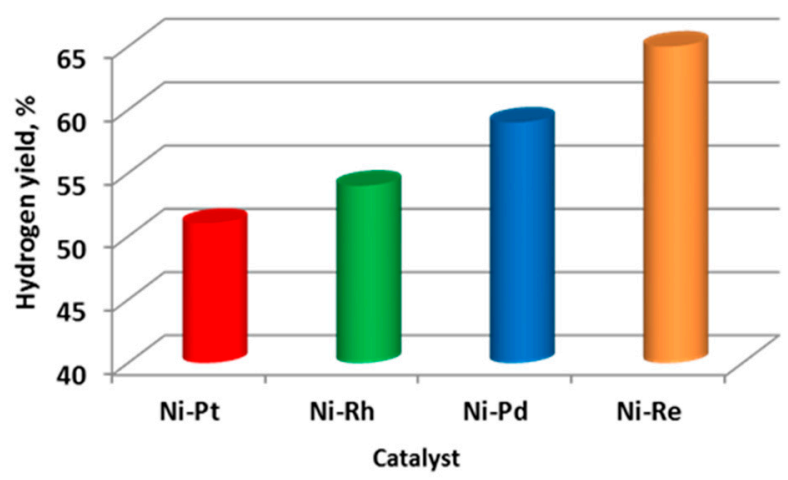

Figure 8. Hydrogen yield in ATR of $\mathrm{C}_{2} \mathrm{H}_{5} \mathrm{OH}$ at $600{ }^{\circ} \mathrm{C}$ over Ni-M-0.012 (C) catalyst: effect promoter type.

The study of catalyst characteristics after ATR of $\mathrm{C}_{2} \mathrm{H}_{5} \mathrm{OH}$ reaction shows that catalysts change their textural and structural properties. The values of $S_{\text {BET }}$ decreased by 2-3 times, while the average pore diameter increases (Table 1). The behavior of the distribution of mesopores in size changed: the portion of large pores increased (Figure 2). It is associated with the intensification of sintering processes under reaction conditions. The increase in the contribution to the porosity of large interparticle pores was observed, which was indicated by the shift of the position of the hysteresis loop to the region of higher values of relative pressure (Figure 2). There is a tendency to increase the activity of catalysts with an increase in their resistance to sintering and retention of textural properties (Tables 1 and 2).

According to XRD data (Figure 2, Table 1), support preserves their phase composition and changes in the phase composition of catalysts are largely associated with changes in the structure of $\mathrm{Ni}$-containing phases. It can be seen that for spent samples in comparison with fresh catalysts, the cell parameter of $\mathrm{CeO}_{2}$-based solid solution practically does not change, but the average crystallite size increases $(8 \rightarrow 13-18 \mathrm{~nm})$ which is associated with the intensification of sintering processes under the reaction conditions, wherein Ni sample is characterized by lower resistance to sintering, and the best is $\mathrm{Ni}-\operatorname{Re}(13 \mathrm{vs} .18 \mathrm{~nm})$. For all samples after the reaction a metallic nickel phase was formed, the average crystallite size was 16-20 nm (Figure 4b). There was no direct correlation between activity and reducibility (Figures 6 and 8 ) in contrast to the literature data [31,50]. All studied Ni and Ni-M catalysts have the capability to self-activation under reaction conditions and can be used without preliminary reduction.

It is noted that the value of the unit cell parameter $(a)$ of $\mathrm{Ni}^{\circ}$ in $\mathrm{Ni}-\mathrm{M}$ catalysts $(\mathrm{M}=\mathrm{Pd}$, $\mathrm{Rh}$, or $\mathrm{Re})$ is larger than $\mathrm{Ni}^{\mathrm{O}}$ reference data $(a=3.523 \AA): 3.532 \AA(\mathrm{M}=\mathrm{Pd}), 3.528 \AA(\mathrm{M}=\mathrm{Rh})$, and $3.538 \AA(\mathrm{M}=\mathrm{Re})$. It is for these catalysts, in contrast to the Ni-Pt sample, that a more significant promotion effect is observed. It indicates the formation of Ni-M alloy that can change the detailed structure of the nanoparticle surface as well as modify electronic metal properties, which affects the activity of the catalysts due to the synergistic effect between metals.

According to the thermal analysis of spent catalysts in air, carbonaceous deposits were formed during the reaction. Their content depended on the catalyst composition and increased in the following row of samples: $\mathrm{Ni}-\mathrm{Pt}(0.3 \%)<\mathrm{Ni} \sim \mathrm{Ni}-\mathrm{Rh}(1.3 \%)<\mathrm{Ni}-\mathrm{Re}(4.5 \%)$ $<\mathrm{Ni}-\mathrm{Pd}(7.5 \%)$. An increase in the activity was accompanied by an increase in the yield of carbonaceous by-products. Thus, a catalysts regeneration procedure should be developed.

It was mentioned above that for the enhancement of $\mathrm{Ni}$ catalyst performance in $\mathrm{H}_{2}$ production through ATR of $\mathrm{C}_{2} \mathrm{H}_{5} \mathrm{OH}$, the most effective promotion was with $\mathrm{Re}$ (Figure 8). This 
sample was distinguished by resistance to sintering, reducibility in the high-temperature region, and the formation of Ni-Re alloy particles which optimized the functional properties of the catalyst due to the synergistic effect between the metals. The developed catalysts provide equilibrium values of ethanol conversion $100 \%$ and hydrogen yield $65 \%$, which is comparable or higher than those described in the literature (Table 3 ) and indicates that they are promising for use in hydrogen energy.

Table 3. Characteristics of the ATP $\mathrm{C}_{2} \mathrm{H}_{5} \mathrm{OH}$ process.

\begin{tabular}{|c|c|c|c|}
\hline Catalyst & Process Conditions & $\begin{array}{c}\mathrm{H}_{2} \text { Yield, } \\
\text { mol } \mathrm{H}_{2} / \mathrm{mol} \\
\mathrm{C}_{2} \mathrm{H}_{5} \mathrm{OH}\end{array}$ & Reference \\
\hline $\begin{array}{c}30 \mathrm{Ni}- \\
1 \mathrm{Rh} / \mathrm{Ce}_{0.5} \mathrm{Zr}_{0.5} \mathrm{O}_{2}\end{array}$ & $\begin{array}{c}\mathrm{C}_{2} \mathrm{H}_{5} \mathrm{OH}: \mathrm{H}_{2} \mathrm{O}: \mathrm{O}_{2}: \mathrm{He}=1: 9: 0.35: 0 \\
\mathrm{~T}=600{ }^{\circ} \mathrm{C}\end{array}$ & 4.6 & [68] \\
\hline $10 \mathrm{Ni} / \mathrm{ZrO}_{2} / \mathrm{Al}_{2} \mathrm{O}_{3}$ & $\begin{array}{c}\mathrm{C}_{2} \mathrm{H}_{5} \mathrm{OH}: \mathrm{H}_{2} \mathrm{O}: \mathrm{O}_{2}: \mathrm{N}_{2}=1: 6: 0: 24.5 \\
\mathrm{~T}=500{ }^{\circ} \mathrm{C} .\end{array}$ & 4.1 & [69] \\
\hline $\begin{array}{c}10 \mathrm{Ni}- \\
0.4 \mathrm{Re} / \mathrm{Ce}_{0.8} \mathrm{La}_{0.2} \mathrm{O}_{1.9}\end{array}$ & $\begin{array}{c}\mathrm{C}_{2} \mathrm{H}_{5} \mathrm{OH}: \mathrm{H}_{2} \mathrm{O}: \mathrm{O}_{2}: \mathrm{He}=1: 3: 0.5: 1 \\
\mathrm{~T}=600{ }^{\circ} \mathrm{C} .\end{array}$ & 4.0 & This work \\
\hline $10 \mathrm{Co} / \mathrm{MgO}-\mathrm{Al}_{2} \mathrm{O}_{3}$ & $\begin{array}{c}\mathrm{C}_{2} \mathrm{H}_{5} \mathrm{OH}: \mathrm{H}_{2} \mathrm{O}: \mathrm{O}_{2}: \mathrm{He}=1: 3: 0.4: 0 \\
\mathrm{~T}=600{ }^{\circ} \mathrm{C} .\end{array}$ & 3.8 & [70] \\
\hline $\mathrm{Co} / \mathrm{Pr} / \mathrm{MgO}-\mathrm{Al}_{2} \mathrm{O}_{3}$ & $\begin{array}{c}\mathrm{C}_{2} \mathrm{H}_{5} \mathrm{OH}: \mathrm{H}_{2} \mathrm{O}: \mathrm{O}_{2}: \mathrm{He}=1: 3: 0.4: 0 \\
\mathrm{~T}=550{ }^{\circ} \mathrm{C} .\end{array}$ & 3.4 & [71] \\
\hline $5 \mathrm{Ni0} .3 \mathrm{Pt} / 10 \mathrm{CeO}_{2} / \mathrm{Al}_{2} \mathrm{O}_{3}$ & $\begin{array}{c}\mathrm{C}_{2} \mathrm{H}_{5} \mathrm{OH}: \mathrm{H}_{2} \mathrm{O}: \mathrm{O}_{2}: \mathrm{He}=1: 8: 0.5: 0 \\
\mathrm{~T}=650{ }^{\circ} \mathrm{C} .\end{array}$ & 3.2 & [72] \\
\hline $0.25 \mathrm{Rh} 0.25 \mathrm{Pt} / \mathrm{ZrO}_{2}$ & $\begin{array}{c}\mathrm{C}_{2} \mathrm{H}_{5} \mathrm{OH}: \mathrm{H}_{2} \mathrm{O}: \mathrm{O}_{2}: \mathrm{He}=1: 2: 0.2: 0 \\
\mathrm{~T}=700{ }^{\circ} \mathrm{C} .\end{array}$ & 3.1 & [73] \\
\hline $\mathrm{LaNiFeO}_{3}$ & $\begin{array}{c}\mathrm{C}_{2} \mathrm{H}_{5} \mathrm{OH}: \mathrm{H}_{2} \mathrm{O}: \mathrm{O}_{2}: \mathrm{He}=1: 3: 0.5: 0 \\
\mathrm{~T}=650{ }^{\circ} \mathrm{C} .\end{array}$ & 3.0 & [74] \\
\hline $\begin{array}{c}10 \mathrm{Ni}^{-} \\
3 \mathrm{Pt} / 30 \mathrm{CeO}_{2} / \mathrm{SiO}_{2}\end{array}$ & $\begin{array}{c}\mathrm{C}_{2} \mathrm{H}_{5} \mathrm{OH}: \mathrm{H}_{2} \mathrm{O}: \mathrm{O}_{2}: \mathrm{He}=1: 3: 0: 0 \\
\mathrm{~T}=750{ }^{\circ} \mathrm{C} .\end{array}$ & 2.4 & [75] \\
\hline $2 \mathrm{Ir} / \mathrm{CeO}_{2}$ & $\begin{array}{c}\mathrm{C}_{2} \mathrm{H}_{5} \mathrm{OH}: \mathrm{H}_{2} \mathrm{O}: \mathrm{O}_{2}: \mathrm{He}=1: 1.8: 0.6: 0 \\
\mathrm{~T}=700{ }^{\circ} \mathrm{C} .\end{array}$ & 2.2 & [76] \\
\hline
\end{tabular}

\section{Conclusions}

An important issue of our time is the development of technologies for the decarbonization of the energy system. This will reduce the greenhouse effect and become the key to the sustainable development of society. A promising carbon-neutral technology is a production of hydrogen from ethanol, the source of which can be a renewable raw material, biomass. Hydrogen is an important reagent and an alternative energy carrier with high ecological properties. In this work, the development of efficient bimetallic catalysts for the production of hydrogen by ATR of $\mathrm{C}_{2} \mathrm{H}_{5} \mathrm{OH}$ was carried out.

A series of $\mathrm{Ni}-\mathrm{M} / \mathrm{Ce}_{0.8} \mathrm{La}_{0.2} \mathrm{O}_{1.9}$ catalysts were prepared at the variation of type $(\mathrm{M}=\mathrm{Pt}, \mathrm{Pd}, \mathrm{Rh}$, and $\mathrm{Re}$ ) and content (molar ratio $\mathrm{M} / \mathrm{Ni}=0.003-0.012)$ of a promoter. The genesis of materials and their properties were systematically studied by thermal analysis, X-ray fluorescence analysis, $\mathrm{N}_{2}$ adsorption, $\mathrm{XRD}$, and TEM. It was found that the prepared catalysts are mesoporous materials with analogous textural properties $\left(S_{\text {BET }}=70 \pm 5 \mathrm{~m}^{2} / \mathrm{g}\right.$, $\mathrm{V}_{\text {pore }}=0.20 \pm 0.01 \mathrm{~cm}^{3} / \mathrm{g}$, and $\left.\mathrm{D}_{\text {pore }}=11.5 \pm 0.9 \mathrm{~nm}\right)$ and phase composition ( $\mathrm{NiO}$ with an average particle size of $18 \pm 1 \mathrm{~nm}$, Ce-La-O solid solution with an average crystallite size of $8.0 \mathrm{~nm}$ ). It was shown that the reducibility of $\mathrm{Ni}^{2+}$ cations is regulated by the type and content of promoter $\mathrm{M}$ as well as the mode of its introduction. It enhances in the following sequence of promoters $\mathrm{Re}<\mathrm{Rh}<\mathrm{Pd}<\mathrm{Pt}$, with an increase in their content, and when using the co-impregnation method. The effect of promoter on the functional properties of catalysts in ATR of $\mathrm{C}_{2} \mathrm{H}_{5} \mathrm{OH}$ was studied, and the optimal composition of the catalyst was selected. The Ni-M/Ce ${ }_{0.8} \mathrm{La}_{0.2} \mathrm{O}_{1.9}$ catalysts have the ability to self-activation under the 
reaction conditions, which makes it possible to exclude the catalyst pre-reduction before the ATR of $\mathrm{C}_{2} \mathrm{H}_{5} \mathrm{OH}$. The catalysts after reaction retain sufficient textural characteristics and dispersion of the active component. To a greater extent, this is observed when rhenium is used as a promoter. With the optimum catalyst $10 \mathrm{Ni}-0.4 \mathrm{Re} / \mathrm{Ce}_{0.8} \mathrm{La}_{0.2} \mathrm{O}_{1.9}$, the high hydrogen yield of $65 \%$ in ATR of $\mathrm{C}_{2} \mathrm{H}_{5} \mathrm{OH}$ was achieved.

Thus, the optimal composition of the catalyst and mode of its preparation were determined. Application of developed $10 \mathrm{Ni}-0.4 \mathrm{Re} / \mathrm{Ce}_{0.8} \mathrm{La}_{0.2} \mathrm{O}_{1.9}$ catalyst for autothermal bioethanol reforming reduces the fossil fuel consumption and provides carbon neutrality of $\mathrm{H}_{2}$ producing technology.

Author Contributions: Conceptualization, M.K. and E.M.; methodology, E.M.; synthesis, E.M.; formal analysis, O.S. (Olga Sukhova); investigation, O.S. (Olga Sukhova), I.I., and O.S. (Olga Stonkus); data curation, M.K.; writing—original draft preparation, E.M.; writing—review and editing, E.M. and M.K.; supervision, Z.I. All authors have read and agreed to the published version of the manuscript.

Funding: This work was supported by the Ministry of Science and Higher Education of the Russian Federation within the governmental order for Boreskov Institute of Catalysis (project AAAA-A21121011490008-3).

Institutional Review Board Statement: Not applicable.

Informed Consent Statement: Not applicable.

Data Availability Statement: Data is contained within the article.

Acknowledgments: The authors are grateful to G.S. Litvak, T.Ya. Efimenko, E.Y. Gerasimiv and V.A. Ushakov for their assistance with catalyst characterization. The TEM studies were carried out using facilities of the shared research centers: "National center of investigation of catalysts" at Boreskov Institute of Catalysis and "VTAN" at Novosibirsk State University.

Conflicts of Interest: The authors declare no conflict of interest.

\section{References}

1. Lupi, V.; Marsiglio, S. Population growth and climate change: A dynamic integrated climate-economy-demography model. Ecol. Econ. 2021, 184, 107011. [CrossRef]

2. Klein, T.; Anderegg, W.R.L. Global warming and urban population growth in already warm regions drive a vast increase in heat exposure in the 21st century. Sustain. Cities Soc. 2021, 73, 103098. [CrossRef]

3. Goeppert, A.; Czaun, M.; Jones, J.P.; Surya Prakash, G.K.; Olah, G.A. Recycling of carbon dioxide to methanol and derived products-closing the loop. Chem. Soc. Rev. 2014, 43, 7995-8048. [CrossRef] [PubMed]

4. Ismagilov, Z.R.; Parmon, V.N. Catalytic methods of processing carbon dioxide from coal generation into useful products. In 10 Breakthrough Ideas in the Field of Energy for the Next 10 Years; Global Energy: Moscow, Russia, 2021; pp. 54-74. Available online: https:/ / globalenergyprize.org/ru/10ideas/ (accessed on 25 June 2021).

5. Akaev, A.A.; Davydova, O.I. A mathematical description of selected energy transition scenarios in the 21st century, intended to realize the main goals of the paris climate agreement. Energies 2021, 14, 2558. [CrossRef]

6. Bulushev, D.A. Progress in catalytic hydrogen production from formic acid over supported metal complexes. Energies 2021, 14, 1334. [CrossRef]

7. Papadis, E.; Tsatsaronis, G. Challenges in the decarbonization of the energy sector. Energy 2020, 205, 118025. [CrossRef]

8. Bloomberg New Energy Finance. Hydrogen Economy Outlook; Bloomberg Finance L.P.: New York, NY, USA, 2020.

9. Cader, J.; Koneczna, R.; Olczak, P. The Impact of Economic, Energy, and Environmental Factors on the Development of the Hydrogen Economy. Energies 2021, 14, 4811. [CrossRef]

10. Dincer, I.; Acar, C. Innovation in hydrogen production. Int. J. Hydrogen Energy 2017, 42, 14843-14864. [CrossRef]

11. Mosińska, M.; Szynkowska-Jóźwik, M.I.; Mierczyński, P. Catalysts for hydrogen generation via oxy-steam reforming of methanol process. Materials 2020, 13, 5601. [CrossRef]

12. Chen, L.; Qi, Z.; Zhang, S.; Su, J.; Somorjai, G.A. Catalytic hydrogen production from methane: A review on recent progress and prospect. Catalysts 2020, 10, 858. [CrossRef]

13. Dawood, F.; Anda, M.; Shafiullah, G.M. Hydrogen production for energy: An overview. Int. J. Hydrogen Energy 2019, 45, 3847-3869. [CrossRef]

14. Le, V.T.; Dragoi, E.N.; Almomani, F.; Vasseghian, Y. Artificial neural networks for predicting hydrogen production in catalytic dry reforming: A systematic review. Energies 2021, 14, 2894. [CrossRef] 
15. Mazhar, A.; Khoja, A.H.; Azad, A.K.; Mushtaq, F.; Naqvi, S.R.; Shakir, S.; Hassan, M.; Liaquat, R.; Anwar, M. Performance Analysis of $\mathrm{TiO}_{2}$-Modified $\mathrm{Co} / \mathrm{MgAl}_{2} \mathrm{O}_{4}$ Catalyst for Dry Reforming of Methane in a Fixed Bed Reactor for Syngas $\left(\mathrm{H}_{2}, \mathrm{CO}\right)$ Production. Energies 2021, 14, 3347. [CrossRef]

16. Quarton, C.J.; Samsatli, S. The value of hydrogen and carbon capture, storage and utilisation in decarbonising energy: Insights from integrated value chain optimisation. Appl. Energy 2020, 257, 113936. [CrossRef]

17. Yu, M.; Wang, K.; Vredenburg, H. Insights into low-carbon hydrogen production methods: Green, blue and aqua hydrogen. Int. J. Hydrogen Energy 2021, 46, 21261-21273. [CrossRef]

18. Minutillo, M.; Perna, A.; Sorce, A. Green hydrogen production plants via biogas steam and autothermal reforming processes: Energy and exergy analyses. Appl. Energy 2020, 277, 115452. [CrossRef]

19. Worawimut, C.; Vivanpatarakij, S.; Watanapa, A.; Wiyaratn, W.; Assabumrungrat, S. Performance evaluation of biogas upgrading systems from swine farm to biomethane production for renewable hydrogen source. Int. J. Hydrogen Energy 2019, 44, 23135-23148. [CrossRef]

20. Chouhan, K.; Sinha, S.; Kumar, S. Simulation of steam reforming of biogas in an industrial reformer for hydrogen production. Int. J. Hydrogen Energy 2021, 46, 26809-26824. [CrossRef]

21. Khila, Z.; Hajjaji, N.; Pons, M.N.; Renaudin, V.; Houas, A. A comparative study on energetic and exergetic assessment of hydrogen production from bioethanol via steam reforming, partial oxidation and auto-thermal reforming processes. Fuel Process. Technol. 2013, 112, 19-27. [CrossRef]

22. Iulianelli, A.; Palma, V.; Bagnato, G.; Ruocco, C.; Huang, Y.; Veziroğlu, N.T.; Basile, A. From bioethanol exploitation to high grade hydrogen generation: Steam reforming promoted by a Co-Pt catalyst in a Pd-based membrane reactor. Renew. Energy 2018, 119, 834-843. [CrossRef]

23. Angili, T.S.; Grzesik, K.; Rödl, A.; Kaltschmitt, M. Life cycle assessment of bioethanol production: A review of feedstock, technology and methodology. Energies 2021, 14, 2939. [CrossRef]

24. Fu, J.; Du, J.; Lin, G.; Jiang, D. Analysis of Yield Potential and Regional Distribution for Bioethanol in China. Energies 2021, 14, 4554. [CrossRef]

25. Annual World Fuel Ethanol Production. Available online: https://ethanolrfa.org/statistics/annual-ethanol-production/ (accessed on 25 June 2021).

26. Nahar, G.; Dupont, V. Hydrogen production from simple alkanes and oxygenated hydrocarbons over ceria-zirconia supported catalysts: Review. Renew. Sustain. Energy Rev. 2014, 32, 777-796. [CrossRef]

27. Nahar, G.; Dupont, V. Recent Advances in Hydrogen Production Via Autothermal Reforming Process (ATR): A Review of Patents and Research Articles. Recent Pat. Chem. Eng. 2013, 6, 8-42. [CrossRef]

28. Sharma, Y.C.; Kumar, A.; Prasad, R.; Upadhyay, S.N. Ethanol steam reforming for hydrogen production: Latest and effective catalyst modification strategies to minimize carbonaceous deactivation. Renew. Sustain. Energy Rev. 2017, 74, 89-103. [CrossRef]

29. Sun, J.; Wang, Y. Recent Advances in Catalytic Conversion of Ethanol to Chemicals. ACS Catal. 2014, 4, 1078-1090. [CrossRef]

30. Hou, T.; Zhang, S.; Chen, Y.; Wang, D.; Cai, W. Hydrogen production from ethanol reforming: Catalysts and reaction mechanism. Renew. Sustain. Energy Rev. 2015, 44, 132-148. [CrossRef]

31. Chagas, C.A.; Manfro, R.L.; Toniolo, F.S. Production of Hydrogen by Steam Reforming of Ethanol over Pd-Promoted $\mathrm{Ni}^{-\mathrm{SiO}_{2}}$ Catalyst. Catal. Lett. 2020, 150, 3424-3436. [CrossRef]

32. Greluk, M.; Rotko, M.; Turczyniak-Surdacka, S. Enhanced catalytic performance of $\mathrm{La}_{2} \mathrm{O}_{3}$ promoted $\mathrm{Co} / \mathrm{CeO}_{2}$ and Ni/CeO catalysts for effective hydrogen production by ethanol steam reforming. Renew. Energy 2020, 155, 378-395. [CrossRef]

33. Olivares, A.C.V.; Gomez, M.F.; Barroso, M.N.; Abello, M.C. Ni-supported catalysts for ethanol steam reforming: Effect of the solvent and metallic precursor in catalyst preparation. Int. J. Ind. Chem. 2018, 9, 61-73. [CrossRef]

34. Vacharapong, P.; Arayawate, S.; Katanyutanon, S.; Toochinda, P.; Lawtrakul, L.; Charojrochkul, S. Enhancement of ni catalyst using $\mathrm{CeO}_{2}-\mathrm{Al}_{2} \mathrm{O}_{3}$ support prepared with magnetic inducement for ESR. Catalysts 2020, 10, 1357. [CrossRef]

35. Sohrabi, S.; Irankhah, A. Synthesis, characterization, and catalytic activity of $\mathrm{Ni} / \mathrm{CeMnO}_{2}$ catalysts promoted by copper, cobalt, potassium and iron for ethanol steam reforming. Int. J. Hydrogen Energy 2021, 46, 12846-12856. [CrossRef]

36. Han, X.; Yu, Y.; He, H.; Shan, W. Hydrogen production from oxidative steam reforming of ethanol over rhodium catalysts supported on Ce-La solid solution. Int. J. Hydrogen Energy 2013, 38, 10293-10304. [CrossRef]

37. Moraes, T.S.; Neto, R.C.R.; Ribeiro, M.C.; Mattos, L.V.; Kourtelesis, M.; Ladas, S.; Verykios, X.; Noronha, F.B. The study of the performance of $\mathrm{PtNi} / \mathrm{CeO}_{2}$-nanocube catalysts for low temperature steam reforming of ethanol. Catal. Today 2015, 242, 35-49. [CrossRef]

38. Liu, Z.; Duchoň, T.; Wang, H.; Peterson, E.W.; Zhou, Y.; Luo, S.; Zhou, J.; Matolín, V.; Stacchiola, D.J.; Rodriguez, J.A.; et al. Mechanistic Insights of Ethanol Steam Reforming over $\mathrm{Ni}-\mathrm{CeO}_{\mathbf{x}}(111)$ : The Importance of Hydroxyl Groups for Suppressing Coke Formation. J. Phys. Chem. C 2015, 119, 18248-18256. [CrossRef]

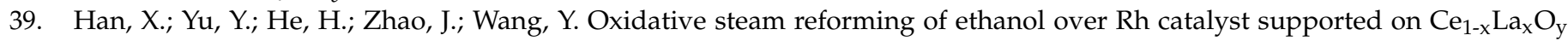
$(x=0.3)$ solid solution prepared by urea co-precipitation method. J. Power Sources 2013, 238, 57-64. [CrossRef]

40. Cai, W.; Wang, F.; Zhan, E.; Van Veen, A.C.; Mirodatos, C.; Shen, W. Hydrogen production from ethanol over Ir/CeO 2 catalysts: A comparative study of steam reforming, partial oxidation and oxidative steam reforming. J. Catal. 2008, 257, 96-107. [CrossRef] 
41. Matus, E.V.; Okhlopkova, L.B.; Sukhova, O.B.; Ismagilov, I.Z.; Kerzhentsev, M.A.; Ismagilov, Z.R. Effects of preparation mode and doping on the genesis and properties of $\mathrm{Ni} / \mathrm{Ce}_{1-\mathrm{x}} \mathrm{M}_{\mathrm{x}} \mathrm{O}_{\mathrm{y}}$ nanocrystallites $(\mathrm{M}=\mathrm{Gd}, \mathrm{La}, \mathrm{Mg})$ for catalytic applications. J. Nanopart. Res. 2019, 21, 11. [CrossRef]

42. Ismagilov, Z.R.; Matus, E.V.; Ismagilov, I.Z.; Sukhova, O.B.; Yashnik, S.A.; Ushakov, V.A.; Kerzhentsev, M.A. Hydrogen production through hydrocarbon fuel reforming processes over Ni based catalysts. Catal. Today 2019, 323, 166-182. [CrossRef]

43. Kerzhentsev, M.A.; Matus, E.V.; Ismagilov, I.Z.; Sukhova, O.B.; Bharali, P.; Ismagilov, Z.R. Control of Ni/Ce $\mathrm{N}_{1-\mathrm{x}} \mathrm{M}_{\mathrm{x}} \mathrm{O}_{\mathrm{y}}$ catalyst properties via the selection of dopant $\mathrm{M}=\mathrm{Gd}, \mathrm{La}, \mathrm{Mg}$. Part 1. Physicochemical characteristics. Eurasian Chem. J. 2018, 20, $283-291$. [CrossRef]

44. Matus, E.V.; Ismagilov, I.Z.; Ushakov, V.A.; Nikitin, A.P.; Stonkus, O.A.; Gerasimov, E.Y.; Kerzhentsev, M.A.; Bharali, P.; Ismagilov, Z.R. Genesis and structural properties of $\left(\mathrm{Ce}_{1-\mathrm{x}} \mathrm{M}_{\mathrm{x}}\right)_{0.8} \mathrm{Ni}_{0.2} \mathrm{O}_{\mathrm{y}}(\mathrm{M}=\mathrm{La}, \mathrm{Mg})$ oxides. J. Struct. Chem. 2020, 61, 1080-1089. [CrossRef]

45. De, S.; Zhang, J.; Luque, R.; Yan, N. Ni-based bimetallic heterogeneous catalysts for energy and environmental applications. Energy Environ. Sci. 2016, 9, 3314-3347. [CrossRef]

46. Dal Santo, V.; Gallo, A.; Naldoni, A.; Guidotti, M.; Psaro, R. Bimetallic heterogeneous catalysts for hydrogen production. Catal. Today 2012, 197, 190-205. [CrossRef]

47. Matus, E.V.; Ismagilov, I.Z.; Yashnik, S.A.; Ushakov, V.A.; Prosvirin, I.P.; Kerzhentsev, M.A.; Ismagilov, Z.R. Hydrogen production through autothermal reforming of $\mathrm{CH} 4$ : Efficiency and action mode of noble $(\mathrm{M}=\mathrm{Pt}, \mathrm{Pd})$ and non-noble $(\mathrm{M}=\mathrm{Re}, \mathrm{Mo}$, Sn) metal additives in the composition of $\mathrm{Ni}-\mathrm{M} / \mathrm{Ce}_{0.5} \mathrm{Zr}_{0.5} \mathrm{O}_{2} / \mathrm{Al}_{2} \mathrm{O}_{3}$ catalysts. Int. J. Hydrogen Energy 2020, 45, 33352-33369. [CrossRef]

48. Kerzhentsev, M.A.; Matus, E.V.; Rundau, I.A.; Kuznetsov, V.V.; Ismagilov, I.Z.; Ushakov, V.A.; Ismagilov, Z.R. Development of a Ni-Pd $/ \mathrm{CeZrO}_{2} / \mathrm{Al}_{2} \mathrm{O}_{3}$ catalyst for the effective conversion of methane into hydrogen-containing gas. Kinet. Catal. 2017, 58, 601-622. [CrossRef]

49. Ismagilov, I.Z.; Matus, E.V.; Kuznetsov, V.V.; Mota, N.; Navarro, R.M.; Yashnik, S.A.; Prosvirin, I.P.; Kerzhentsev, M.A.; Ismagilov, Z.R.; Fierro, J.L.G. Hydrogen production by autothermal reforming of methane: Effect of promoters (Pt, Pd, Re, Mo, Sn) on the performance of $\mathrm{Ni} / \mathrm{La}_{2} \mathrm{O}_{3}$ catalysts. Appl. Catal. A Gen. 2014, 481, 104-115. [CrossRef]

50. Moretti, E.; Storaro, L.; Talon, A.; Chitsazan, S.; Garbarino, G.; Busca, G.; Finocchio, E. Ceria-zirconia based catalysts for ethanol steam reforming. Fuel 2015, 153, 166-175. [CrossRef]

51. Trane-Restrup, R.; Dahl, S.; Jensen, A.D. Steam reforming of ethanol: Effects of support and additives on Ni-based catalysts. Int. J. Hydrogen Energy 2013, 38, 15105-15118. [CrossRef]

52. Akdim, O.; Cai, W.; Fierro, V.; Provendier, H.; Veen, A.; Shen, W.; Mirodatos, C. Oxidative Steam Reforming of Ethanol over $\mathrm{Ni}-\mathrm{Cu} / \mathrm{SiO}_{2}, \mathrm{Rh} / \mathrm{Al}_{2} \mathrm{O}_{3}$ and $\mathrm{Ir} / \mathrm{CeO}_{2}$ : Effect of Metal and Support on Reaction Mechanism. Top. Catal. 2008, 51, 22-38. [CrossRef]

53. Moraes, T.S.; Rabelo Neto, R.C.; Ribeiro, M.C.; Mattos, L.V.; Kourtelesis, M.; Ladas, S.; Verykios, X.; Noronha, F.B. Ethanol conversion at low temperature over $\mathrm{CeO}_{2}$-Supported Ni-based catalysts. Effect of Pt addition to Ni catalyst. Appl. Catal. B Environ. 2016, 181, 754-768. [CrossRef]

54. Pereira, E.B.; Homs, N.; Martí, S.; Fierro, J.L.G.; Ramírez de la Piscina, P. Oxidative steam-reforming of ethanol over Co/SiO 2 , $\mathrm{Co}-\mathrm{Rh} / \mathrm{SiO}_{2}$ and $\mathrm{Co}-\mathrm{Ru} / \mathrm{SiO}_{2}$ catalysts: Catalytic behavior and deactivation/regeneration processes. J. Catal. 2008, 257, 206-214. [CrossRef]

55. Chen, L.C.; Lin, S.D. The ethanol steam reforming over $\mathrm{Cu}-\mathrm{Ni} / \mathrm{SiO}_{2}$ catalysts: Effect of $\mathrm{Cu} / \mathrm{Ni}$ ratio. Appl. Catal. B Environ. 2011, 106, 639-649. [CrossRef]

56. Kerzhentsev, M.A.; Matus, E.V.; Ismagilov, I.Z.; Ushakov, V.A.; Stonkus, O.A.; Larina, T.V.; Kozlova, G.S.; Bharali, P.; Ismagilov, Z.R. Structural and morphological properties of $\mathrm{Ce}_{1-\mathrm{x}} \mathrm{M}_{\mathrm{x}} \mathrm{O}_{\mathrm{y}}(\mathrm{M}=\mathrm{Gd}, \mathrm{La}, \mathrm{Mg})$ supports for the catalysts of autothermal ethanol conversion. J. Struct. Chem. 2017, 58, 133-141. [CrossRef]

57. Kerzhentsev, M.A.; Matus, E.V.; Ismagilov, I.Z.; Sukhova, O.B.; Bharali, P.; Ismagilov, Z.R. Control of Ni/Ce $1-\mathrm{x} \mathrm{M}_{\mathrm{x}} \mathrm{O}_{\mathrm{y}}$ Catalyst Properties Via the Selection of Dopant M = Gd, La, Mg. Part 2. Catalytic Activity. Eurasian Chem. J. 2018, 20, 293-300. [CrossRef]

58. Li, D.; Nakagawa, Y.; Tomishige, K. Methane reforming to synthesis gas over Ni catalysts modified with noble metals. Appl. Catal. A Gen. 2011, 408, 1-24. [CrossRef]

59. Ji, H.; Cho, S. Steam-to-carbon ratio control strategy for start-up and operation of a fuel processor. Int. J. Hydrogen Energy 2017, 42, 9696-9706. [CrossRef]

60. Lee, S.H.D.; Applegate, D.V.; Ahmed, S.; Calderone, S.G.; Harvey, T.L. Hydrogen from natural gas: Part I-Autothermal reforming in an integrated fuel processor. Int. J. Hydrogen Energy 2005, 30, 829-842. [CrossRef]

61. Mikuli, E.; Migdal-Mikuli, A.; Chyzy, R.; Grad, B.; Dziembaj, R. Melting and thermal decomposition of $\left[\mathrm{Ni}\left(\mathrm{H}_{2} \mathrm{O}\right)_{6}\right]\left(\mathrm{NO}_{3}\right)_{2}$ Thermochim. Acta 2001, 370, 65-71. [CrossRef]

62. Chen, K.; Zhang, T.; Chen, X.; He, Y.; Lang, X. Model construction of micro-pores in shale: A case study of Silurian Longmaxi Formation shale in Dianqianbei area, SW China. Pet. Explor. Dev. 2018, 45, 412-421. [CrossRef]

63. Zhao, P.; Qin, F.; Huang, Z.; Sun, C.; Shen, W.; Xu, H. Morphology-dependent oxygen vacancies and synergistic effects of $\mathrm{Ni} / \mathrm{CeO}_{2}$ catalysts for $\mathrm{N}_{2} \mathrm{O}$ decomposition. Catal. Sci. Technol. 2018, 8, 276-288. [CrossRef]

64. Montoya, J.A.; Romero-Pascual, E.; Gimon, C.; Del Angel, P.; Monzon, A. Methane reforming with $\mathrm{CO}_{2}$ over $\mathrm{Ni}_{2} / \mathrm{ZrO}_{2}-\mathrm{CeO}_{2}$ catalysts prepared by sol-gel. Catal. Today 2000, 63, 71-85. [CrossRef]

65. Pan, Z.; Ding, Y.; Jiang, D.; Li, X.; Jiao, G.; Luo, H. Study on Ni-Re-K/ $\mathrm{Al}_{2} \mathrm{O}_{3}$ catalysts for synthesis of $\mathrm{N}, \mathrm{N}^{\prime}$-di-sec-butyl p-phenylene diamine from p-nitroaniline and 2-butanone. Appl. Catal. A Gen. 2007, 330, 43-48. [CrossRef] 
66. Bobadilla, L.F.; Romero-Sarria, F.; Centeno, M.A.; Odriozola, J.A. Promoting effect of Sn on supported Ni catalyst during steam reforming of glycerol. Int. J. Hydrogen Energy 2016, 41, 9234-9244. [CrossRef]

67. Sharifi, M.; Haghighi, M.; Rahmani, F.; Karimipour, S. Syngas production via dry reforming of $\mathrm{CH}_{4}$ over Co- and Cu-promoted $\mathrm{Ni} / \mathrm{Al}_{2} \mathrm{O}_{3}-\mathrm{ZrO}_{2}$ nanocatalysts synthesized via sequential impregnation and sol-gel methods. J. Nat. Gas. Sci. Eng. 2014, 21, 993-1004. [CrossRef]

68. Mondal, T.; Pant, K.K.; Dalai, A.K. Catalytic oxidative steam reforming of bio-ethanol for hydrogen production over Rh promoted $\mathrm{Ni} / \mathrm{CeO}_{2}-\mathrm{ZrO}_{2}$ catalyst. Int. J. Hydrogen Energy 2015, 40, 2529-2544. [CrossRef]

69. Han, S.J.; Bang, Y.; Seo, J.G.; Yoo, J.; Song, I.K. Hydrogen production by steam reforming of ethanol over mesoporous $\mathrm{Ni}^{-\mathrm{Al}_{2} \mathrm{O}_{3}-}$ $\mathrm{ZrO}_{2}$ xerogel catalysts: Effect of $\mathrm{Zr} / \mathrm{Al}$ molar ratio. Int. J. Hydrogen Energy 2013, 38, 1376-1383. [CrossRef]

70. Espitia-Sibaja, M.; Muñoz, M.; Moreno, S.; Molina, R. Effects of the cobalt content of catalysts prepared from hydrotalcites synthesized by ultrasound-assisted coprecipitation on hydrogen production by oxidative steam reforming of ethanol (OSRE). Fuel 2017, 194, 7-16. [CrossRef]

71. Muñoz, M.; Moreno, S.; Molina, R. Synthesis of Ce and Pr-promoted Ni and Co catalysts from hydrotalcite type precursors by reconstruction method. Int. J. Hydrogen Energy 2012, 37, 18827-18842. [CrossRef]

72. Profeti, L.P.R.; Ticianelli, E.A.; Assaf, E.M. Production of hydrogen via steam reforming of biofuels on $\mathrm{Ni}_{1} / \mathrm{CeO}_{2}-\mathrm{Al}_{2} \mathrm{O}_{3}$ catalysts promoted by noble metals. Int. J. Hydrogen Energy 2009, 34, 5049-5060. [CrossRef]

73. Gutierrez, A.; Karinen, R.; Airaksinen, S.; Kaila, R.; Krause, A.O.I. Autothermal reforming of ethanol on noble metal catalysts. Int. J. Hydrogen Energy 2011, 36, 8967-8977. [CrossRef]

74. Huang, L.; Zhang, F.; Wang, N.; Chen, R.; Hsu, A.T. Nickel-based perovskite catalysts with iron-doping via self-combustion for hydrogen production in auto-thermal reforming of Ethanol. Int. J. Hydrogen Energy 2012, 37, 1272-1279. [CrossRef]

75. Palma, V.; Ruocco, C.; Meloni, E.; Ricca, A. Oxidative steam reforming of ethanol on mesoporous silica supported Pt-Ni/CeO 2 catalysts. Int. J. Hydrogen Energy 2017, 42, 1598-1608. [CrossRef]

76. Cai, W.; Wang, F.; Daniel, C.; Van Veen, A.C.; Schuurman, Y.; Descorme, C.; Provendier, H.; Shen, W.; Mirodatos, C. Oxidative steam reforming of ethanol over $\mathrm{Ir} / \mathrm{CeO}_{2}$ catalysts: A structure sensitivity analysis. J. Catal. 2012, 286, 137-152. [CrossRef] 